\title{
MACROECONOMIC IMPACT OF BASEL III: EVIDENCE FROM A META-ANALYSIS.
}

\author{
JARKO FIDRMUC, RONJA LIND
}


(C) Národná banka Slovenska

www.nbs.sk

Imricha Karvaša 1

81325 Bratislava

research@nbs.sk

August 2017

The views expressed in this paper do not necessarily reflect the views of the National Bank of Slovakia or the Eurosystem.

All rights reserved. 


\title{
Macroeconomic Impact of Basel III: Evidence from a Meta-Analysis ${ }^{1}$
}

\author{
Jarko Fidrmuc ${ }^{2}$, Ronja Lind ${ }^{3}$
}

\begin{abstract}
We present a meta-analysis of the impact of higher capital requirements imposed by regulatory reforms on the macroeconomic activity (Basel III). The empirical evidence derived from a unique dataset of 48 primary studies indicates that there is a negative, albeit moderate GDP level effect in response to a change in the capital ratio. The effects are likely to be slightly stronger but still low for the CEECs. Meta-regression results suggest that the estimates reported in the literature tend to be systematically influenced by a selected set of study characteristics, such as econometric specifications, the authors' affiliations, and the underlying financial system. Finally, we document a significant positive publication bias.
\end{abstract}

JEL classification: E51, E44, G28

Keywords: Meta-analysis, Bayesian model averaging, publication bias, banking, capital requirements, Basel III

\footnotetext{
${ }^{1}$ We wish to thank Tom Stanley, Chris Doucouliagos, Tomáš Havránek, Roman Horváth, Caroline Stern, Martin Šuster, Thomas Apolte, Iikka Korhonen, Kilian Seng, Angela De Martiis and participants of the joint Annual Meeting of the Slovak Economic Association and the Austrian Economic Association in Bratislava in May 2016, IFABS conference in Barcelona in June 2016, the biannual research conference of the NBS on "Monetary Policy Challenges from a Small Country Perspective" in November 2016, and numerous seminars for useful comments. Jarko Fidrmuc thanks the National Bank of Slovakia for the hospitality. The usual disclaimer applies.

2 Corresponding Address: Zeppelin University Friedrichshafen, Am Seemooser Horn 20, 88045 Friedrichshafen, Germany, Tel.: +49 75416009 1241, Fax: +49 75416009 1499, jarko.fidrmuc@zu.de.

${ }^{3}$ Zeppelin University Friedrichshafen, Am Seemooser Horn 20, 88045 Friedrichshafen, Germany, r.lind@zeppelin-university.net.
} 


\section{INTRODUCTION}

In light of the 2008 financial crisis, global regulators agreed on a substantial increase in capital and liquidity requirements for financial institutions. As bank failures and bailout programs have compellingly shown, major international banks entered the crisis with inadequate capital levels relative to their risk exposure (Admati et al., 2013a and 2013b). In December 2010, with regard to the regulatory deficiencies revealed by the crisis, the Basel Committee on Banking Supervision (BCBS) announced extensive reforms to strengthen the resilience of the financial system, known as Basel III (BCBS, 2010a). There are indeed strong arguments that the Basel reforms will make the banking system safer, reducing bank risktaking ex ante (Kim and Santomero, 1988; Holmstrom and Tirole, 1997) and the probability of bank default ex post (Dewatripont and Tirole, 1994; Gambacorta and Mistrulli, 2004). At the same time, we observe a consensus among policymakers and financial sector participants that the implementation of the Basel rules will impose significant costs on the banking system and the broader economy (IIF, 2011). The effects could be even higher in CEECs (Reifner et al., 2011).

Assessing the economic trade-off between economic development and systemic financial stability has become a core concern of the post-crisis era. Despite a growing empirical literature on the topic, we still know surprisingly little about effects of macro-prudential policy. While there is general agreement that capital regulation will be costly, the arguments behind this view remain opaque (Noss and Toffano, 2016). The empirical evidence on macro-financial linkages presents also an ambiguous picture. Although most Basel III impact studies find robust negative effects, results are surprisingly heterogeneous (ranging from weak to strong impact). In light of these drawbacks, this paper aims to explain the 
heterogeneity of results by analysing its determinants in a systematic and explicit way, applying meta-analysis techniques. To the best of our knowledge, this is the first study conducting a meta-analysis on this topic. Synthesizing the empirical evidence from a unique dataset of more than 312 estimates reported in 48 primary studies (see Appendix, Table A.1), the findings suggest that, on average, there is a negative, albeit moderate GDP level effect in response to a marginal change in the capital ratio. The GDP level is expected to decrease by about $0.20 \%$ as a response to an increase in the capital ratio by 1 percentage point. In contrast to the theoretical discussion, all reported study estimates are negative. However, as we show, the empirical results of the surveyed studies are driven by various study characteristics (e.g. the econometric methodology and their regional focus). Moreover, statistical evidence can be found that the estimates of the surveyed studies may be distorted by significant publication bias.

The contribution of this paper is twofold. First, the assessment of regulatory impacts is of high policy interest. We provide a systematic review that allows us to draw a more coherent picture. The meta-results may be more reliable compared to individual studies that are highly selective and biased. Second, we identify substantial caveats in the calibration of regulatory impacts. While the previous meta-analysis, in general, did not concentrate on simulation studies, we discuss the methods how to assess publication bias for those analyses. Finally, we differ between weak and strong effects, which is also a novel approach in meta-analysis.

The remainder of this paper is structured as follows. Section 2 presents a short literature review on the assessment of regulatory impacts. Section 3 introduces the meta-analysis framework. Section 4 presents the meta-dataset and meta-statistics. Section 5 shows that publication bias analysis is more important than initially expected. As a part of this discussion, we discuss how to measure quality or preciseness for simulation studies. Section 
6 presents the standard meta-analysis and Bayesian model averaging results. The robustness of main results is discussed in Section 7. Moreover, the robustness analysis discusses the differences between studies reporting strong and negligible effects. Section 8 concludes. 


\section{MEASURING REGULATORY IMPACTS}

Any assessment of the macroeconomic impact of the Basel reforms requires an understanding of the linkage between capital regulation, bank behaviour and the real economy. This is a field that has largely been neglected in the past decades (Friedman, 1991). As a consequence, the empirical literature on regulatory impacts still lacks a unified theoretical framework. In light of the financial crisis, the predominant role of bank capital became obvious and is recently integrated into macro models through several transmission channels. The bank balance sheet channel reflects that adverse shocks to financial institutions' balance sheets (due to internal losses or external policy changes) result in significant contractions in credit supply and economic growth (BCBS, 2011). While the traditional bank lending channel (Bernanke and Gertler, 1995) focuses on explicit monetary policy shocks, the bank capital channel assumes that banks cut down lending in response to exogenous shocks to their capitalization (Van den Heuvel, 2008; Meh and Moran, 2010). These shocks may either arise from financial sector shocks (e.g. fluctuations in asset prices) or may be attributed to regulatory capital requirements.

Within this framework, an introduction of higher regulatory capital requirements, as envisaged in Basel III, will lead to a transitional shortfall in bank capital (in form of a gap between actual and target capital ratio). This effect may be reinforced by procyclicality if asset losses and risk weights increase in economic downturns. As regulators will sanction a shortfall in bank capital, banks are forced to react by changing their resource allocation and loan pricing to increase their capital levels at least until they reach the regulatory minimum. In general, banks are expected to either increase their interest margins or cut down lending. 
There are, however, alternative strategies that will not affect the lending channel (e.g. if banks cut down expenses).

Recently, a variety of econometric methodologies have been developed to evaluate the impact of the Basel reforms (for a more detailed description, see Appendix, Table B.1). The most frequently used models, especially by central banks, follow a two-step approach (proposed by MAG, 2010a). In a first step, satellite models are used to predict banks' adjustment to achieve the minimum capital ratio. The proxy variables (changes in lending volumes and credit spreads) obtained from satellite models may later serve as input factors into large-scale (semi-structural or DSGE-based) macroeconomic policy models provided by policy institutions (e.g. the QUEST model at the European Commission; Roeger and Veld, 2004). While policy models are powerful for forecasting, a direct investigation of macroprudential policy changes is not possible in many cases. The two-step approach tackles the issue using satellite models, which rely on either explicit regression-based approaches (whenever appropriate bank-level data is available) or simpler accounting-based approaches (in the absence of such data). Within the regression-based approaches econometric inference is either based on changes in lending volumes, as proposed by the target capital ratio model (Hancock and Wilcox, 1993 and 1994; Francis and Osborne, 2009) or on changes in credit spreads based on the credit-spread model (Barrell, 2009).

The target capital ratio model first calculates the gap between the actual and the target capital ratio and derives a 'distance-from-target variable that is then used to regress the responses of different balance sheet items. Similarly, the credit-spread model is based on spread effects from elasticities estimated from historical data. Most spread models rely on panel regressions, whereby a quarterly change in lending spreads is regressed on increased capital requirements and other control variables. In contrast, accounting-based models 
mainly rely on simple balance sheet identities by a loan-pricing model that derives the lending spreads that keep the ROE constant (Elliott, 2009; Slovik and Cournede, 2011). While this approach is intuitive, the degree of pass-through is a critical assumption and interaction effects are not captured.

An alternative approach are DSGE models that explicitly feature a banking sector and allow to derive the steady-state impact of increased capital requirements on the real economy (Meh and Moran, 2010; Angelini and Gerali, 2011), however, results are highly sensitive to the calibration of parameters. Partial equilibrium models that focus on the credit market represent a less complex alternative (De Nicolo, 2015). Cointegration models (VECM, ECM) estimate a long-term relationship between a small set of macro variables using bank data and allow disentangling demand and supply factors of the lending channel (Angelini et al., 2011; Gambacorta, 2011). Moreover, there are some models relying on a simple production function, calibrating the elasticity of output to changes in firm's cost of capital (BoE, 2010; Miles et al., 2011). Finally, large-scale macro models of central banks and other institutions are used (Locarno, 2011). While two-step approaches (MAG, 2010b) are commonly accepted and yield similar and robust results, the use of alternative approaches is relatively new, leading to a high degree of uncertainty. 


\section{META-REGRESSION METHODOLOGY AND SOURCES OF RESULT HETEROGENEITY}

A comprehensive meta-analysis combines a variety of statistical techniques that are useful in reviewing and evaluating the empirical literature in a specific field of research. As such, it is a powerful instrument to assess variation among reported results, hereby determining the impact of study characteristics and providing a type of consensus (Stanley, 2001; Stanley and Jarrell, 2005). Recently, there is a growing number of meta-analyses on economic policy issues, for instance on business cycle correlation (Fidrmuc and Korhonen, 2006 and 2015), international monetary economics (Havránek and Iršová, 2011, Havránek et al., 2015) or labour economics (Card et al., 2010). In contrast, the meta-analysis approach is new in banking and finance. Feld et al. (2013) present e.g. a meta-analysis on a capital structure choice.

In general, any meta-analysis is based on the regression between a summary statistic (the dependent variable) and a set of study characteristics (the independent variables), drawn from each paper. A meta-regression model is therefore given by

$$
\widehat{b S}_{k i}=\mu+\sum_{l=1}^{L} \beta_{l} D_{l k i}+u_{k i}
$$

where $\widehat{b s l}$ refers of Basel III impact in study $k$ and $D_{l}$ represents variables describing selected study characteristics, while $u$ is the error term.

A crucial point for any meta-analysis is the comparability of reported effects, e.g. $\widehat{b s l}$. Following the literature, we measure the impact of higher capital requirements on the real economy as percentage change in the level of GDP in response to a 1 percentage point change in the capital-to-asset-ratio (BCBS, 2010; MAG, 2010). This can be referred to as the 
marginal effect of increased capital ratios (irrespective of underlying model classes). However, some studies use alternative input factors (e.g. 1.3 percentage point increase in capital ratios to cover the whole Basel III impact, as proposed by BCBS, 2010b). Hence, the effect size reported in primary studies must be at least transformable to a marginal effect. Several authors suggest that the effects may be linearly convertible into a marginal effect across models (MAG, 2010; Angelini et al., 2015).

The majority of the studies (over 70 percent) report long-term effects of Basel regulations. For estimation studies (e.g. VAR models, and macroeconomic forecasting models) this implies the impact at the end of the forecasting horizon (e.g. 10 or 20 years). For simulation studies (DSGE) models, this is the difference between the steady state in different policy scenarios.

We expect five variable groups to affect the reported estimates. In the first group, we include variables for the publication year and the publication format (journal, working paper, policy reports, etc.). While the publication year may detect a trend in the analysis, the publication format accounts for possible quality differences. The second group includes dummy variables accounting for authors' affiliation (academic, banking or public sector and specific organizations), as political interests and expectations may affect the reported results.

Third, the regional focus of the study may result in cross-country variations, as different countries are expected to be more or less affected by higher capital requirements (Cosimano and Hakura, 2011). On the one hand, we distinguish between bank-based and market-based financial systems (Levine and Zervos, 1998; Levine, 2002). In general, bank-based systems may be more affected by banking regulation (Beck and Levine, 2002 and 2004). On the other hand, La Porta et al. (1998) categorize countries with respect to their legal origins. 
Fourth, different estimation methods may drive the results. Finally, further modelling assumptions are considered, as a longer phase-in period, as well as a long-term estimate and favourable monetary policy may reduce the effects of higher capital requirements.

The exact variable definitions can be found in Appendix (Table A.2) and descriptive statistics in Table A.3. With the exception of the demeaned publication year variable (deviation from the mean publication year), all other variables are binary. 


\section{DATASET AND META-STATISTICS}

We review 48 primary studies on the macroeconomic cost of higher capital requirements. A full list of the reviewed studies is presented in Appendix, Table A.1. The underlying selection process can be described as follows. Relevant studies were identified searching the EconLit database, IDEAS, Google Scholar, and ScienceDirect. In addition, important journals and working paper series were scanned. To identify all relevant studies, we used a variety of search key words (i.e., 'capital requirements', 'capital ratio', and 'Basel III') as of May 2016. The main selection criterion requires that potential studies report estimates of the GDP level effect in response to a marginal change in the capital ratio. Otherwise, this marginal effect must at least be linearly convertible from the reported result. In order to avoid overrepresentation, only the most recent version of a paper is included (e.g. earlier working paper versions are ignored), with the exception of revised papers providing significantly different results. Furthermore, only recent papers (Basel III impact studies) are included, as methods of previous studies are not directly comparable. Finally, this meta-analysis follows the standard approach of including all estimates provided by one study (Stanley, 2001, 2005, and 2008). In particular, there is a priori no clear criterion suggesting which estimate to include. Moreover, a variation in one dimension ceteris paribus may be valuable for metaregressions and the within-study variance will be used as a measure for precision in our publication bias analysis. 


\section{Figure 1. Number of publications by year and publication format}

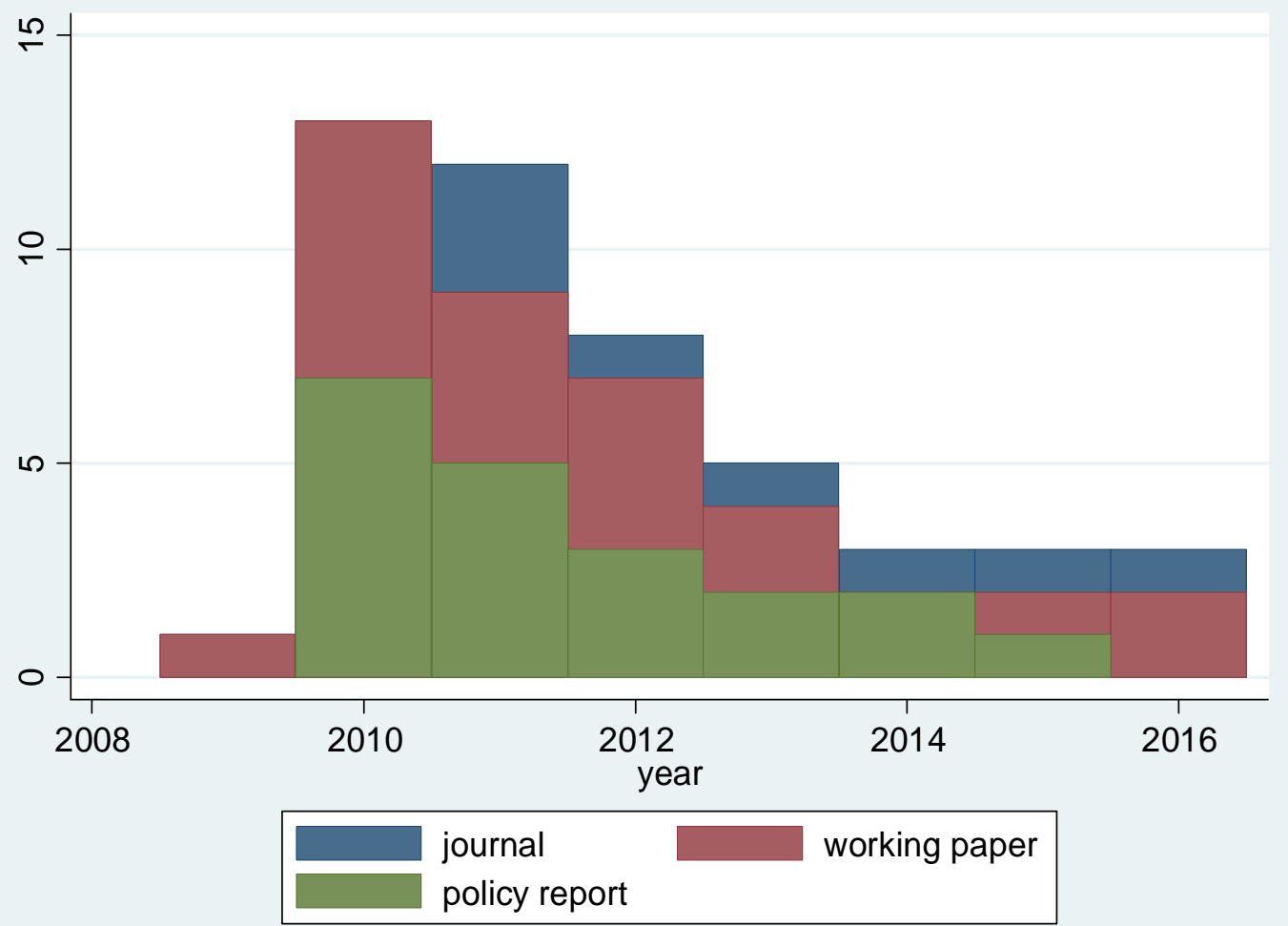

Note: Data for 2016 are available only from January to May 2016.

Source: Own estimations.

Figure 1 presents the number of publications by year and the publication format. In the first years after the Basel announcement, there has been a surge of interest. Moreover, policy reports and working paper dominated the discussion in the first years. Most of the working papers have reached high attention and are assumed to be of relatively high quality. With regard to the authors' affiliations, public sector organizations seem to participate more actively in the regulation debate. Most studies are published by central banks, followed by the IMF.

Table 1 reports meta-statistics for the overall dataset and selected subsamples. The descriptive statistics show already several important findings. First, the average estimated 
macroeconomic impact of higher capital requirements across all studies and observations is negative, albeit moderate. On average, each percentage point increase in the capital ratio leads to a $0.20 \%$ GDP level decrease in the long run. Second, the estimated effect ranges from $-0.85 \%$ to $-0.01 \%$, thus, there are no positive values. This is a surprising finding, given that theoretical papers do not clearly predict a negative effect (e.g., Van den Heuvel, 2008). Third, strong variations across selected variable groups can be identified. On average, public sector studies tend to report negligible impact of Basel regulations as compared to banking sector studies. Similarly, market-based financial systems are generally found to be less affected by Basel III than the bank-based financial systems. Moreover, results vary for different legal origins and the model classes employed in the primary studies. However, the reported results do not substantially vary for different years (descriptive statistics are available upon request). Finally, the meta-sample distribution of regulation effect estimates (Figure 2) is negatively skewed. In general, researches tend to discard positive estimates. This finding is further investigated in the publication bias analysis.

\section{Figure 2. Histogram of reported impact of Basel III}

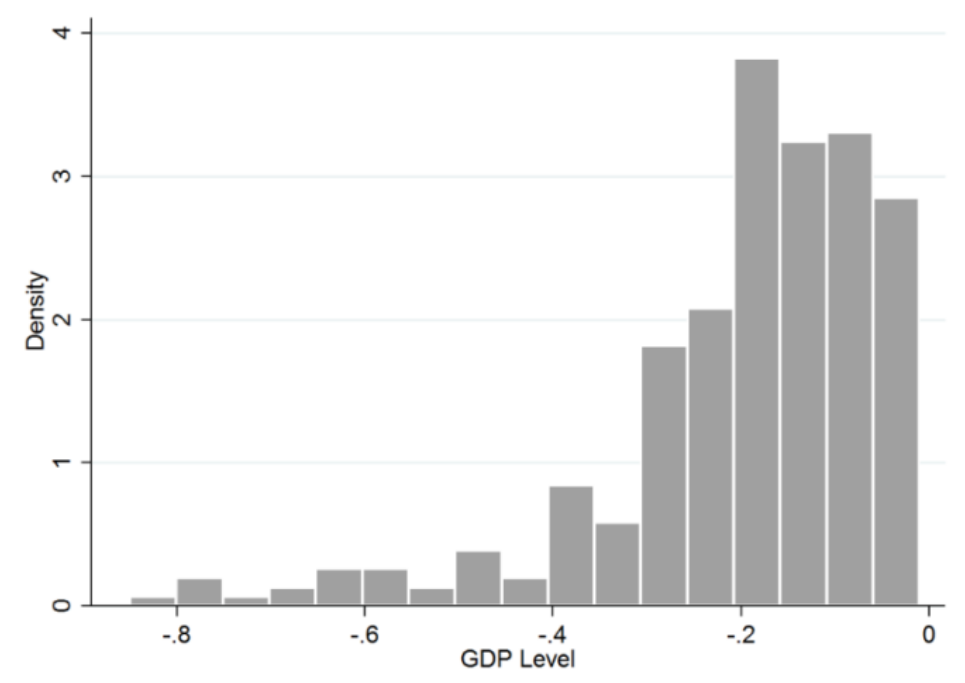


Table 1: Meta-statistics of reported impact of Basel III by selected variables

Variables No of obs. $\quad$ Mean

Std. Dev.

Min

Max

A. Meta-statistics for the total sample

\begin{tabular}{|c|c|}
\hline & 312 \\
\hline B. Meta-statistics by authors' affiliations
\end{tabular}

$-0.198$

0.009

$-0.85$

$-0.01$

\begin{tabular}{|c|c|}
\hline BIS & 87 \\
\hline Central Bank & 65 \\
\hline IMF & 57 \\
\hline European Institution & 3 \\
\hline OECD & 15 \\
\hline FSA & 2 \\
\hline Public sector & 262 \\
\hline Banking sector & 28 \\
\hline Academic sector & 22 \\
\hline
\end{tabular}

\begin{tabular}{l|l}
87 & \\
65 & \\
57 &
\end{tabular}

$-0.194$

0.104

$-0.56$

\begin{tabular}{l|l}
0.147 & -0.85
\end{tabular}

$-0.04$

\begin{tabular}{l|l}
56 & -0.189
\end{tabular}

$-0.141$

0.116

$-0.50$

$-0.01$

$15-0.153$

0.097

$-0.39$

$-0.01$

$2 \quad-0.060$

0.064

$-0.30$

$-0.05$

\begin{tabular}{ll}
2 & -0.174 \\
\hline
\end{tabular}

$28 \quad-0.425$

0.028

$-0.08$

$-0.04$

22

$-0.193$

0.117

$-0.85$

$-0.04$

Academic sector

system

\begin{tabular}{|c|c|}
\hline C. Meta-statistics by financial sys & 238 \\
\hline Bank-based system & 74 \\
\hline
\end{tabular}

D. Meta-statistics by legal origin

\begin{tabular}{|c|r|}
\hline English origin & 80 \\
\hline French origin & 43 \\
\hline German origin & 33 \\
\hline Scandinavian origin & 11 \\
\hline Other origin & 145 \\
\hline
\end{tabular}

\begin{tabular}{l|l}
\hline 238 & -0.20 \\
\hline 74 & -0.17
\end{tabular}

$-0.206$

$-0.171$

0.275

$-0.80$

$-0.01$

$-0.04$

$\begin{array}{ll}-0.42 & -0.01\end{array}$

\section{E. Meta-statistics by model class}

\begin{tabular}{|c|c|c|c|c|c|}
\hline Regression-based & 77 & -0.212 & 0.119 & -0.65 & -0.04 \\
\hline Median estimate & 20 & -0.164 & 0.077 & -0.36 & -0.09 \\
\hline Mean estimate & 19 & -0.225 & 0.103 & -0.54 & -0.11 \\
\hline Accounting-based & 60 & -0.288 & 0.228 & -0.80 & -0.01 \\
\hline VAR & 19 & -0.319 & 0.169 & -0.85 & -0.04 \\
\hline DSGE & 35 & -0.133 & 0.116 & -0.45 & -0.01 \\
\hline Macro-structural & 72 & -0.124 & 0.085 & -0.35 & -0.01 \\
\hline Production function & 10 & -0.080 & 0.045 & -0.15 & -0.01 \\
\hline \multicolumn{6}{|c|}{ F. Meta-statistics by variables describing modelling assumptions } \\
\hline Long-term estimate & 223 & -0.202 & 0.171 & -0.85 & -0.01 \\
\hline Long-term impl. horizon & 274 & -0.189 & 0.142 & -0.85 & -0.01 \\
\hline Monetary policy offset & 53 & -0.108 & 0.122 & -0.80 & -0.01 \\
\hline
\end{tabular}




\section{Table 2: Meta-statistics of reported impact of Basel III by countries}

\begin{tabular}{|c|c|c|c|c|c|}
\hline Country/Region & No of obs. & Mean & Std. Dev. & Min & Max \\
\hline Australia & 3 & -0.033 & 0.040 & -0.080 & -0.010 \\
\hline Austria & 9 & -0.199 & 0.092 & -0.350 & -0.070 \\
\hline Belgium & 1 & -0.110 & ND & -0.110 & -0.110 \\
\hline Brazil & 4 & -0.095 & 0.048 & -0.140 & -0.030 \\
\hline Bulgaria & 1 & -0.220 & ND & -0.220 & -0.220 \\
\hline Canada & 22 & -0.147 & 0.113 & -0.380 & -0.010 \\
\hline China & 4 & -0.172 & 0.113 & -0.290 & -0.030 \\
\hline Cyprus & 1 & -0.050 & ND & -0.050 & -0.050 \\
\hline Czech Rep. & 1 & -0.360 & ND & -0.360 & -0.360 \\
\hline Denmark & 1 & -0.290 & ND & -0.290 & -0.290 \\
\hline EU & 23 & -0.241 & 0.204 & -0.780 & -0.050 \\
\hline Estonia & 1 & -0.360 & ND & -0.360 & -0.360 \\
\hline Finland & 1 & -0.250 & ND & -0.250 & -0.250 \\
\hline France & 6 & -0.182 & 0.101 & -0.300 & -0.040 \\
\hline Germany & 5 & -0.148 & 0.079 & -0.250 & -0.050 \\
\hline Global & 106 & -0.205 & 0.126 & -0.640 & -0.030 \\
\hline Greece & 1 & -0.110 & ND & -0.110 & -0.110 \\
\hline Hong Kong & 1 & -0.040 & ND & -0.040 & -0.040 \\
\hline Hungary & 1 & -0.210 & ND & -0.210 & -0.210 \\
\hline India & 3 & -0.273 & 0.075 & -0.350 & -0.200 \\
\hline Ireland & 1 & -0.160 & ND & -0.160 & -0.160 \\
\hline Italy & 9 & -0.181 & 0.083 & -0.330 & -0.030 \\
\hline Japan & 7 & -0.294 & 0.314 & -0.800 & -0.040 \\
\hline Korea & 7 & -0.180 & 0.132 & -0.410 & -0.010 \\
\hline Latvia & 1 & -0.370 & ND & -0.370 & -0.370 \\
\hline Lithuania & 1 & -0.320 & ND & -0.320 & -0.320 \\
\hline Luxemburg & 1 & -0.090 & ND & -0.090 & -0.090 \\
\hline Malaysia & 2 & -0.250 & 0.297 & -0.460 & -0.040 \\
\hline Malta & 1 & -0.090 & ND & -0.090 & -0.090 \\
\hline Mexico & 2 & -0.130 & 0.099 & -0.200 & -0.060 \\
\hline Netherlands & 11 & -0.164 & 0.125 & -0.400 & -0.030 \\
\hline Norway & 4 & -0.083 & 0.015 & -0.100 & -0.070 \\
\hline Philippines & 1 & -0.010 & ND & -0.010 & -0.010 \\
\hline Poland & 1 & -0.250 & ND & -0.250 & -0.250 \\
\hline Portugal & 1 & -0.120 & ND & -0.120 & -0.120 \\
\hline Romania & 1 & -0.080 & ND & -0.080 & -0.080 \\
\hline Russia & 2 & -0.260 & 0.057 & -0.300 & -0.220 \\
\hline Slovakia & 1 & -0.220 & ND & -0.220 & -0.220 \\
\hline Slovenia & 1 & -0.290 & ND & -0.290 & -0.290 \\
\hline South Africa & 2 & -0.240 & 0.014 & -0.250 & -0.230 \\
\hline Spain & 4 & -0.310 & 0.263 & -0.640 & -0.040 \\
\hline Sweden & 5 & -0.222 & 0.165 & -0.500 & -0.060 \\
\hline Switzerland & 5 & -0.324 & 0.317 & -0.740 & -0.050 \\
\hline Turkey & 1 & -0.420 & ND & -0.420 & -0.420 \\
\hline UK & 17 & -0.176 & 0.229 & -0.850 & -0.010 \\
\hline US & 28 & -0.187 & 0.185 & -0.800 & -0.010 \\
\hline
\end{tabular}


We report selected descriptive statistics for individual countries in Table 2. Most studies focus on the US (28 observations). The importance of the US is further stressed by the high number of global studies (106 observations). The number of observations is also comparably high for Canada (22), the UK (17), and the Netherlands (11). For the EU countries, the majority of studies present only the EU average (23).

The country results show that he CEECs will be more affected by the Basel III regulations than other countries (average of $-0.27 \%$ of GDP). This is mainly due to high importance of the banking and low domestic financial resources. For Slovakia, Reifner et al. (2011) forecast a relatively moderate impact of $-0.22 \%$ of GDP. The highest negative impact is expected for the Baltic States $(-0.32 \%$ to $-0.36 \%)$, and Slovenia $(-0.29 \%)$. These effects are largely similar to other emerging economies dependent on banking sector: $-0.42 \%$ in Turkey, $-0.24 \%$ in South Africa, and $-0.26 \%$ in Russia. In contrast, other emerging markets could be less affected by Basel III: $-0.17 \%$ in China, $-0.13 \%$ in Mexico, and $-0.10 \%$ in Brazil. However, we have to keep in mind that the figures are based on a very low number of observations per country (only 1 to 5 observations).

\section{PUBLICATION BIAS ANALYSIS}

\subsection{PROXY FOR AVERAGE PRECISION OF SURVEYED STUDIES}

In the first part of our analysis, we evaluate whether publication selection bias is present in the empirical literature on Basel III impacts. Publication bias is a common phenomenon in scientific research, whereby results are more likely to be published if they are statistically significant or theoretically desirable and this might, in turn, induce a selection process of empirical findings that biases the true population parameter. As a result, the knowledge about a particular economic relationship is clearly limited. One common approach for 
detecting publication selection bias is to analyze the relationship between the reported result and its precision (Card and Krueger, 1995; Stanley and Doucouliagos, 2012). If there is no publication bias, there should be no systematic relationship between reported results and their precision. However, the presence of publication bias will induce a correlation between the estimate and its precision. We expect a relatively strong 'consensus' that capital regulation has adverse effects on GDP, although the economic theory does not clearly support a negative effect (VanHoose, 2007).

A conventional proxy for precision is the inverse of the standard error, $1 / S E$. Alternatively, Card and Krueger (1995) use degrees of freedom. However, since our analysis includes various model classes, standard errors or degrees of freedom are not available in many cases, especially in simulation studies. Nevertheless, precision can be proxied by other quality indicators. We propose an alternative measure for precision using the within-studies standard deviation in order to deal with quality differences in more comprehensive way. To the best of our knowledge, previous studies did not discuss publication bias in simulations studies. Thus, our approach provides an extension of the methodology of publication bias analysis.

Accurate studies should present several estimates within a relatively narrow range. Correspondingly we propose the average precision of studies, APS, which uses the standard deviation, $S D_{k}=\frac{1}{N_{k}} \sum_{i}\left(\widehat{b S}_{k i}-\overline{b s}_{k}\right)$ of individual results reported by an $k$ study, $b s l_{k i}, i=$ $1, \ldots, N_{k}$. This approach reflects that the studies with lesser-reported differences present more reliable findings. In contrast, less precise studies are associated with a higher variation 
of reported results. Standard deviation is, however, not defined for studies reporting only one estimate, which is also indicating a lower reliability of the presented estimate. In this case, we set the precision proxy to zero, assuming that these studies were conducted with a comparably low methodological rigor. ${ }^{4}$ The definition of the precision variable is summarized as

$$
A P S_{k}=\left\{\begin{array}{cl}
\frac{1}{S D_{k}} & \text { if } N_{k}>1 \\
0 & \text { if } N_{k}=1
\end{array}\right. \text {. }
$$

\subsection{FUNNEL PLOTS AND FUNNEL ASSYMETRY TESTS}

Funnel plots represent the most intuitive way to visualize publication selection bias. A funnel graph is a scatter diagram that plots the precision of the reported effect on the vertical axis against the measured effect size on the horizontal axis (Sutton et al., 2000a and 200b). In the absence of publication bias, the estimates should be randomly and symmetrically distributed around the 'true' effect. The plot is expected to resemble an inverted funnel, with the more precise estimates being located close to the 'true' effect. In contrast, publication bias may be significant if the funnel plot appears asymmetric in case of directional selection or hollow and wide.

The funnel plot relying on our APS measure for reported studies is displayed in Figure 3. Two important findings emerge from its visual investigation. First, the figure does not resemble

\footnotetext{
${ }^{4}$ For studies using VAR models, we compare our measure of the average precision of studies with the quality of VAR models, as proxied by the number of included variables. The correlation of both precision proxies is relatively high (0.11). The funnel plots are highly similar for both indicators. The results are available from authors upon request.
} 
an inverted funnel, but appears asymmetrically skewed to the left, which implies a downward bias in the surveyed literature. This might indicate a strong selective reporting as researchers discard higher (especially positive) estimates too often, but we have to keep in mind possible caveats of our measure of preciseness. The shape becomes even more apparent as points with the precision set to zero (for $\mathrm{N}=1$ ) are not considered (diamond symbols). Obviously, some studies report estimates close to zero, but they are avoiding positive estimates. This lopsided plot is even more remarkable as the theoretical literature does not clearly support a one-sided, negative effect of higher capital ratios. Nonetheless, even in case of a clearly negative effect, the estimates should vary symmetrically around most precise estimates. Second, the effect magnitude is not clear. While the average of all 312 estimates is about -0.20 , the most precise estimates are only -0.05 percentage of GDP. Hence, single studies tend to overestimate the effect size. While the average result seems to be significant in economic terms, the most reliable studies report only a negligible impact of Basel III.

In order to test for publication bias in a more formal way (Card and Krueger, 1995; Ashenfelter et al., 1999), we use funnel asymmetry test (FAT). As far as we have only average proxy of study precision, we use a simple meta-regression of average estimates and corresponding average precision 


\section{Figure 3. Funnel plot, Average Effects of Basel III}

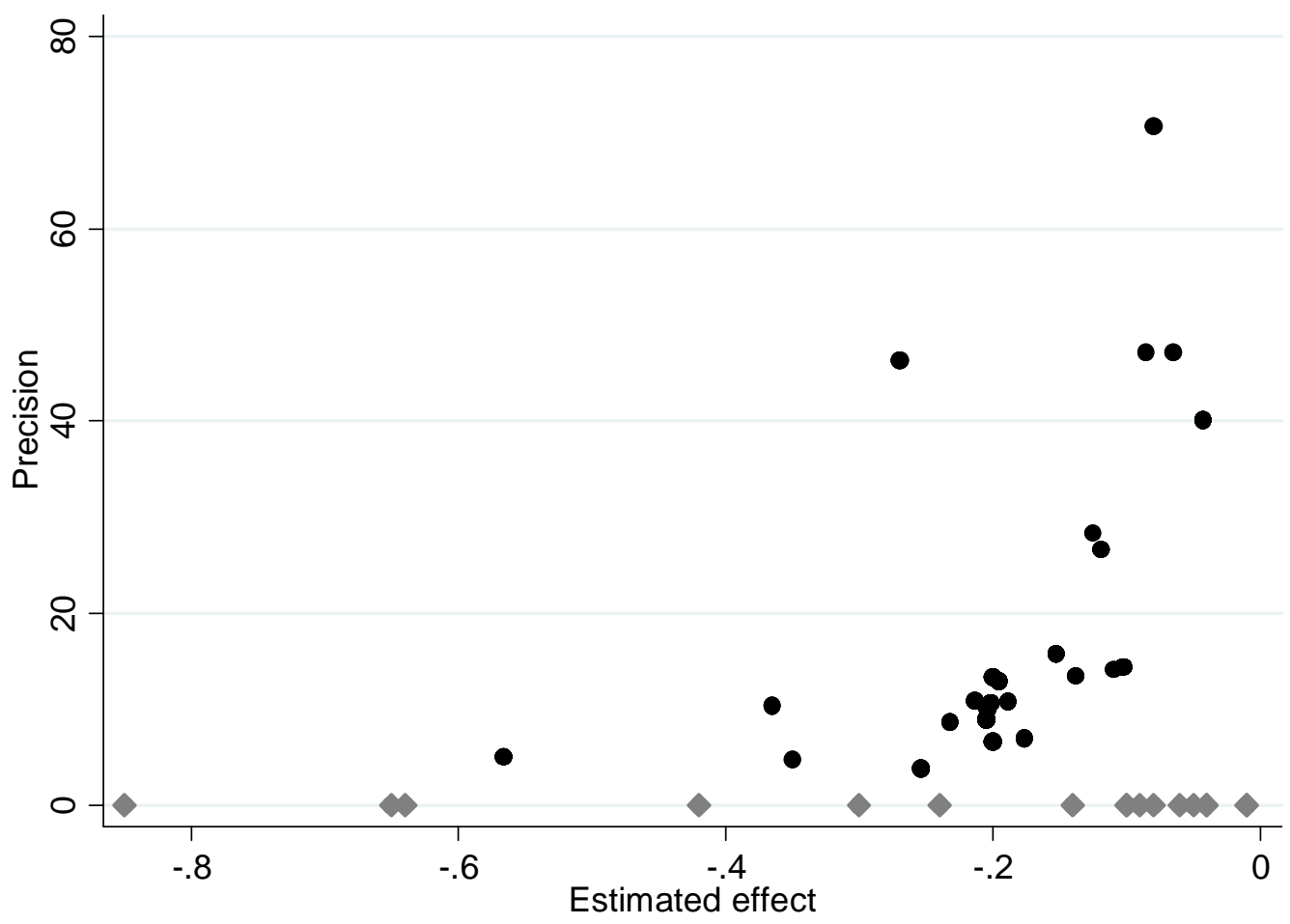

Note: The precision variable is defined as the inverse within-studies standard deviation. For $N=1$ the precision indicator is set to zero (diamond symbols).

Source: Own estimations.

\begin{tabular}{|c|c|c|c|c|}
\hline & (1) & (2) & (3) & (4) \\
\hline & OLS & WLS & OLS & WLS \\
\hline \multirow[t]{2}{*}{ Publication bias, $\alpha$} & -0.465 & -1.035 & $-1.242 * * *$ & $-1.396^{* *}$ \\
\hline & $(0.385)$ & $(0.522)$ & $(0.416)$ & $(0.647)$ \\
\hline Observations & 48 & 48 & 26 & 26 \\
\hline $\mathrm{R}^{2}$ & 0.026 & 0.230 & 0.475 & 0.464 \\
\hline \multicolumn{5}{|c|}{$\begin{array}{l}\text { Note: WLS - weighted tests using the number of reported estimates. Robust standard } \\
\text { errors are in parentheses. **, and *** denote significance at the } 5 \% \text {, and } 1 \% \text { level, } \\
\text { respectively. } \\
\text { Source: Own estimations. }\end{array}$} \\
\hline
\end{tabular}




$$
\overline{b s l}_{k}=\alpha A P S_{k}+b s l+\varepsilon_{k i}
$$

where $\overline{b s l}=\frac{1}{N} \sum_{i} \widehat{b s}_{i}$ is the average reported effect, $b s /$ stands for the 'true effect', coefficient $\alpha$ show the publication bias and $\varepsilon$ is the error term. If there is no evidence for publication bias, the coefficient $\alpha$ should be not significantly different from zero, given that the estimates vary symmetrically around the 'true effect'. In contrast, publication bias can be detected if $\alpha$ is non-zero and significant. The error term $\varepsilon$ is, however, expected to be heteroscedastic as studies rely on different econometric specifications. To address the issue of quality differences among studies and to obtain efficient estimates, the standard approach is refined using weighted least squares (WLS). Most WLS specifications use the inverse standard errors as weights, giving more weight to more precise estimates. We use the number of reported estimates as a measure for precision, and thus as weights in the WLS specification. The corresponding FAT test for $\alpha=0$ detects publication bias if its null hypothesis of no publication bias can be rejected (Egger et al., 1997).

Table 3 presents OLS and WLS versions of FAT test with robust standard errors at the studylevel. We exclude studies with only one estimate in specification (3) and (4), since this measurement is less reliable. The FAT results confirm fully the findings derived from the funnel plots for studies reporting more than only one estimate, which reject the null hypothesis of no publication bias. 


\section{BAYESIAN MODEL AVERAgING META- REGRESSION ANALYSIS}

We adopt Bayesian model averaging (BMA) methodology in order to assess the degree of model uncertainty attached to the meta-regressions for the impact of Basel III regulations. The BMA has become an important tool to deal with model uncertainty in meta-analysis in economics (Havránek and Rusnák, 2013, Havránek et al., 2015). The main advantage of the BMA approach is that it considers all possible combinations of explanatory variables and weights them according to the model fits. In addition, the BMA results are robust to model uncertainty, when the true set of explanatory variables is largely unknown. Thus we consider all possible specification where Basel III impacts are explained by all possible combinations of explanatory variables. Our data set includes altogether 28 possible explanatory variables. This gives us a model space with 228 which is more than 300 million possible models. Moreover, we compare the BMA results with the Bayesian weighted-average least-squares (WALS) estimator, which relies on the Laplace priors to select the important auxiliary regressors.

The key statistic of BMA (Table 4) is the posterior inclusion probability (PIP) which reflects the importance of each variable. Using as a criterion PIP above 0.50 (alternatively using 0.95 or 0.75 ) we can see that the most robust determinants of reported effects of Basel III are dummy variables for bank policy reports, countries with market-based financial systems (with PIP of 0.95 ), VAR models, and the accompanying design of monetary policy. 
Table 4: Bayesian meta-regression and model selection

\begin{tabular}{|c|c|c|c|c|c|c|c|c|c|c|c|c|c|}
\hline & \multicolumn{4}{|c|}{ BMA } & \multicolumn{3}{|c|}{ WALS } & \multicolumn{3}{|c|}{ General model } & \multicolumn{3}{|c|}{ Preferred specification } \\
\hline & Coef. & Std.Err. & PIP & & Coef. & Std.Err. & & Coef. & Std.Err. & & Coef. & Std.Err. & \\
\hline Publication year & 0.000 & 0.001 & 0.05 & & 0.011 & 0.007 & & 0.016 & 0.011 & & 0.003 & 0.008 & \\
\hline Journal & -0.001 & 0.007 & 0.04 & & -0.043 & 0.049 & & -0.078 & 0.051 & & & & \\
\hline Working paper & 0.002 & 0.008 & 0.08 & & 0.011 & 0.055 & & 0.004 & 0.057 & & & & $* *$ \\
\hline Public policy report & -0.002 & 0.008 & 0.07 & ++ & -0.027 & 0.052 & & -0.049 & 0.053 & & -0.246 & 0.051 & $*$ \\
\hline Bank policy report & -0.312 & 0.034 & 1.00 & + & -0.168 & 0.110 & & -0.220 & 0.143 & & & & \\
\hline Banking sector & 0.001 & 0.021 & 0.04 & & -0.020 & 0.099 & & -0.002 & 0.107 & & & & $* *$ \\
\hline BIS & -0.001 & 0.006 & 0.06 & & 0.079 & 0.055 & & 0.124 & 0.056 & $* *$ & 0.044 & 0.029 & $*$ \\
\hline Central Bank & 0.000 & 0.004 & 0.04 & & 0.077 & 0.050 & & 0.120 & 0.054 & $* *$ & 0.044 & 0.026 & $* *$ \\
\hline IMF & 0.000 & 0.004 & 0.04 & & 0.037 & 0.055 & & 0.052 & 0.055 & & & & \\
\hline Europ. Institution & 0.000 & 0.005 & 0.04 & & 0.080 & 0.051 & & 0.116 & 0.063 & $*$ & 0.058 & 0.031 & $\begin{array}{l}* * \\
* *\end{array}$ \\
\hline OECD & 0.002 & 0.011 & 0.06 & & 0.088 & 0.062 & & 0.119 & 0.064 & $\begin{array}{l}* \\
* *\end{array}$ & 0.096 & 0.033 & $\begin{array}{l}* \\
* *\end{array}$ \\
\hline FSA & 0.007 & 0.034 & 0.07 & & 0.198 & 0.092 & $* *$ & 0.260 & 0.056 & $*$ & 0.175 & 0.035 & $*$ \\
\hline Bank-based system & -0.001 & 0.009 & 0.06 & & 0.011 & 0.028 & & 0.029 & 0.033 & & & & \\
\hline Market-based system & 0.068 & 0.028 & 0.91 & ++ & 0.062 & 0.048 & & 0.089 & 0.060 & & 0.060 & 0.020 & $* * *$ \\
\hline French origin & 0.009 & 0.020 & 0.22 & & 0.031 & 0.046 & & 0.044 & 0.053 & & & & \\
\hline German origin & -0.002 & 0.010 & 0.06 & & -0.010 & 0.047 & & -0.003 & 0.054 & & & & \\
\hline Scandinavian origin & 0.000 & 0.008 & 0.04 & & 0.007 & 0.056 & & 0.016 & 0.064 & & & & \\
\hline Other origin & -0.007 & 0.018 & 0.18 & & -0.008 & 0.044 & & -0.006 & 0.053 & & & & \\
\hline Mean estimate & -0.007 & 0.020 & 0.13 & & -0.014 & 0.033 & & -0.020 & 0.034 & & & & \\
\hline $\begin{array}{l}\text { Median estimate } \\
\text { Accountina-based }\end{array}$ & 0.001 & 0.008 & 0.05 & & 0.027 & 0.032 & & 0.042 & 0.031 & & & & \\
\hline models & 0.000 & 0.004 & 0.04 & ++ & 0.027 & 0.031 & $* *$ & 0.050 & 0.034 & $* *$ & & & \\
\hline VAR models & -0.134 & 0.029 & 1.00 & + & -0.092 & 0.033 & $*$ & -0.110 & 0.040 & $\begin{array}{l}* \\
* *\end{array}$ & -0.102 & 0.040 & $* *$ \\
\hline DSGE models & 0.000 & 0.005 & 0.04 & & 0.063 & 0.029 & $* *$ & 0.079 & 0.028 & $*$ & 0.042 & 0.022 & $\begin{array}{l}* \\
* *\end{array}$ \\
\hline Macro-structural models & 0.001 & 0.007 & 0.07 & & 0.061 & 0.032 & $*$ & 0.073 & 0.038 & $\begin{array}{l}* \\
* *\end{array}$ & 0.068 & 0.025 & $\begin{array}{l}* \\
* *\end{array}$ \\
\hline Production function & 0.012 & 0.032 & 0.16 & & 0.107 & 0.049 & $* *$ & 0.135 & 0.041 & $*$ & 0.097 & 0.023 & $*$ \\
\hline Long-term estimate & 0.000 & 0.004 & 0.04 & & -0.003 & 0.019 & & -0.002 & 0.020 & & & & \\
\hline Long-term impl. horizon & 0.001 & 0.006 & 0.05 & & 0.016 & 0.022 & & 0.009 & 0.026 & & & & \\
\hline & & & & ++ & & & $* *$ & & & $* *$ & & & $* *$ \\
\hline Monetary policy offset & 0.095 & 0.019 & 1.00 & $\begin{array}{l}+ \\
++\end{array}$ & 0.072 & 0.017 & $\begin{array}{l}* \\
* *\end{array}$ & 0.097 & 0.021 & $\begin{array}{l}* \\
* *\end{array}$ & 0.103 & 0.020 & $*$ \\
\hline Intercept & -0.194 & 0.020 & 1.00 & + & -0.310 & 0.061 & $*$ & -0.359 & 0.074 & $*$ & -0.259 & 0.028 & $* * *$ \\
\hline
\end{tabular}

Note:,,++++++ denote if PIP indicates that the significance is decisive (PIP is above 0.99$)$, strong (0.95), positive (0.75), respectively. Robust standard errors are reported for the general model and the preferred specification. Reference categories (omitted variables): other publication format; authors affiliated with academic sector; mixed financial system, English legal origin; regression-based approach. *,**, and *** denote significance at the 10\%, 5\%, and 1\% level, respectively.

Source: Own estimations. 
Table 5: Robustness analysis, estimation methods

\begin{tabular}{|c|c|c|c|c|c|c|}
\hline & $\begin{array}{l}(0) \\
\text { PREF }\end{array}$ & $\begin{array}{l}(1) \\
\text { WLS }\end{array}$ & $\begin{array}{l}(2) \\
\text { LAD }\end{array}$ & $\begin{array}{l}\text { (3) } \\
\text { RR }\end{array}$ & $\begin{array}{l}\text { (4) } \\
\text { CFE }\end{array}$ & $\begin{array}{l}\text { (5) } \\
\text { SRE }\end{array}$ \\
\hline Publication year & $\begin{array}{l}0.003 \\
(0.008)\end{array}$ & $\begin{array}{l}-0.010 \\
(0.015)\end{array}$ & $\begin{array}{l}0.002 \\
(0.004)\end{array}$ & $\begin{array}{l}0.002 \\
(0.004)\end{array}$ & $\begin{array}{l}0.005 \\
(0.008)\end{array}$ & $\begin{array}{l}-0.009 \\
(0.017)\end{array}$ \\
\hline Bank policy report & $\begin{array}{l}-0.246 * * * \\
(0.051)\end{array}$ & $\begin{array}{l}-0.335^{* * *} \\
(0.073)\end{array}$ & $\begin{array}{l}-0.328^{* * *} \\
(0.025)\end{array}$ & $\begin{array}{l}-0.407^{* * *} \\
(0.028)\end{array}$ & $\begin{array}{l}-0.250 * * * \\
(0.067)\end{array}$ & $\begin{array}{l}-0.318^{* * *} \\
(0.088)\end{array}$ \\
\hline BIS & $\begin{array}{l}0.044 \\
(0.029)\end{array}$ & $\begin{array}{l}0.018 \\
(0.054)\end{array}$ & $\begin{array}{l}0.044 * * \\
(0.020)\end{array}$ & $\begin{array}{l}0.039 * \\
(0.022)\end{array}$ & $\begin{array}{l}0.034 \\
(0.027)\end{array}$ & $\begin{array}{l}0.016 \\
(0.054)\end{array}$ \\
\hline Central Bank & $\begin{array}{l}0.044 * \\
(0.026)\end{array}$ & $\begin{array}{l}0.022 \\
(0.048)\end{array}$ & $\begin{array}{l}0.044 * * \\
(0.018)\end{array}$ & $\begin{array}{l}0.054 * * * \\
(0.020)\end{array}$ & $\begin{array}{l}0.032 \\
(0.043)\end{array}$ & $\begin{array}{l}0.018 \\
(0.056)\end{array}$ \\
\hline Europ. Institution & $\begin{array}{l}0.058 * \\
(0.031)\end{array}$ & $\begin{array}{l}0.003 \\
(0.055)\end{array}$ & $\begin{array}{l}0.052 * * \\
(0.023)\end{array}$ & $\begin{array}{l}0.037 \\
(0.025)\end{array}$ & $\begin{array}{l}0.065 \\
(0.046)\end{array}$ & $\begin{array}{l}0.040 \\
(0.047)\end{array}$ \\
\hline OECD & $\begin{array}{l}0.096 * * * \\
(0.033)\end{array}$ & $\begin{array}{l}0.052 \\
(0.058)\end{array}$ & $\begin{array}{l}0.102 * * * \\
(0.029)\end{array}$ & $\begin{array}{l}0.079 * * \\
(0.032)\end{array}$ & $\begin{array}{l}0.100 * * \\
(0.043)\end{array}$ & $\begin{array}{l}0.057 \\
(0.048)\end{array}$ \\
\hline FSA & $\begin{array}{l}0.175^{* * *} \\
(0.035)\end{array}$ & $\begin{array}{l}0.123 * \\
(0.070)\end{array}$ & $\begin{array}{l}0.176 * * * \\
(0.049)\end{array}$ & $\begin{array}{l}0.166 * * \\
(0.070)\end{array}$ & $\begin{array}{l}0.283 \\
(0.171)\end{array}$ & $\begin{array}{l}0.117 * \\
(0.068)\end{array}$ \\
\hline Market-based system & $\begin{array}{l}0.060 * * * \\
(0.020)\end{array}$ & $\begin{array}{l}0.024 \\
(0.040)\end{array}$ & $\begin{array}{l}0.040 * * * \\
(0.013)\end{array}$ & $\begin{array}{l}0.026^{*} \\
(0.014)\end{array}$ & $\begin{array}{l}0.123 \\
(0.167)\end{array}$ & $\begin{array}{l}0.063 * * \\
(0.029)\end{array}$ \\
\hline VAR models & $\begin{array}{l}-0.102 * * \\
(0.040)\end{array}$ & $\begin{array}{l}-0.130 \\
(0.103)\end{array}$ & $\begin{array}{l}-0.090 * * * \\
(0.022)\end{array}$ & $\begin{array}{l}-0.092 * * * \\
(0.024)\end{array}$ & $\begin{array}{c}-0.123 * \\
(0.064)\end{array}$ & $\begin{array}{l}-0.107 * * \\
(0.051)\end{array}$ \\
\hline DSGE models & $\begin{array}{l}0.042 * \\
(0.022)\end{array}$ & $\begin{array}{l}0.079 * * \\
(0.036)\end{array}$ & $\begin{array}{l}0.062 * * * \\
(0.018)\end{array}$ & $\begin{array}{l}0.057 * * * \\
(0.020)\end{array}$ & $\begin{array}{l}0.067 * * \\
(0.032)\end{array}$ & $\begin{array}{l}0.029 \\
(0.057)\end{array}$ \\
\hline Macro-structural models & $\begin{array}{l}0.068 * * * \\
(0.025)\end{array}$ & $\begin{array}{l}0.017 \\
(0.049)\end{array}$ & $\begin{array}{l}0.080 * * * \\
(0.019)\end{array}$ & $\begin{array}{l}0.064 * * * \\
(0.021)\end{array}$ & $\begin{array}{l}0.077 * * \\
(0.032)\end{array}$ & $\begin{array}{l}0.029 \\
(0.034)\end{array}$ \\
\hline Production function & $\begin{array}{l}0.097 * * * \\
(0.023)\end{array}$ & $\begin{array}{l}0.106 * * * \\
(0.036)\end{array}$ & $\begin{array}{l}0.118^{* * *} \\
(0.026)\end{array}$ & $\begin{array}{l}0.097 * * * \\
(0.033)\end{array}$ & $\begin{array}{l}0.126 * * * \\
(0.037)\end{array}$ & $\begin{array}{l}0.087 * * * \\
(0.023)\end{array}$ \\
\hline Monetary policy offset & $\begin{array}{l}0.103^{* * *} \\
(0.020)\end{array}$ & $\begin{array}{l}0.074 * \\
(0.039)\end{array}$ & $\begin{array}{l}0.100 * * * \\
(0.014)\end{array}$ & $\begin{array}{l}0.078 * * * \\
(0.015)\end{array}$ & $\begin{array}{l}0.094 * * * \\
(0.021)\end{array}$ & $\begin{array}{l}0.085^{* * *} \\
(0.022)\end{array}$ \\
\hline Intercept & $\begin{array}{l}-0.259 * * * \\
(0.028)\end{array}$ & $\begin{array}{l}-0.213^{* * *} \\
(0.055)\end{array}$ & $\begin{array}{l}-0.251^{* * *} \\
(0.019)\end{array}$ & $\begin{array}{l}-0.235^{* * *} \\
(0.021)\end{array}$ & $\begin{array}{l}-0.273^{* * *} \\
(0.046)\end{array}$ & $\begin{array}{l}-0.225^{* * *} \\
(0.046)\end{array}$ \\
\hline No. of obs. & 312 & 312 & 312 & 312 & 312 & 312 \\
\hline $\mathrm{R}^{2} /$ Pseudo $\mathrm{R}^{2}$ & 0.424 & 0.416 & 0.227 & 0.691 & 0.453 & 0.399 \\
\hline
\end{tabular}

Note: Column (1) to (5) present robustness analysis methods. PREF - preferred specification (see Table 3). WLS weighted least squares regression. $L A D$ - least absolute deviation (median regression). RR - Cook's distance robust regression. CFE - country fixed effects regression. SRE - study random effects regression. Robust standard errors are in parentheses. * **, and *** denote significance at the $10 \%, 5 \%$, and $1 \%$ level, respectively.

Source: Own estimations. 
The WALS results confirm the importance of these variables possibly except the market-based financial systems. Moreover, they also indicate that publication year and the dummies for results published by the authors affiliated with the Bank of International Settlements, European Commission, and financial supervision authorities may play an important role in understanding of the reported effects. Moreover, studies applying DSGE models and macro-econometric models and production functions are also significant. A comparison with standard OLS results in column (3) shows that institutional and methodological variables are at least marginally significant.

Based on the identification of robust variables by the BMA and WALS methodology, we present the preferred specification in the last part of the Table 4. All identified variables except the publication year remain significant in this final specification.

Finally, we present also the results for the general model in order to derive hypothetical benchmark results of a study which is not subject to any bias due to its methodological or publication properties. Following Feld et al. (2013), the benchmark results exclude significant variables and consider the sample mean for the remaining explanatory variables. Thus, the benchmark results implicitly refer to the "average study" of the sample. Using the intercept and insignificant coefficients presented in Table 3, we get a predicted benchmark impact of Basel III of about -0.32 percent of GDP. ${ }^{5}$

\footnotetext{
${ }^{5}$ In particular, this estimate is derived as: $0.016 * 0.000(\mathrm{ydm})-0.078 * 0.067$ (pjournal) $+0.004 * 0.554(\mathrm{pwp})$ - $0.049 * 0.212$ (pupr) - $0.220 * 0.083$ (prpr) - $0.002 * 0.090$ (abank) + $0.052 * 0.183$ (aimf) $+0.029 * 0.667$ (bbased) $+0.089 * 0.237$ (mbased) $+0.044 * 0.138$ (frenchor) $-0.003 * 0.106$ (germanor) $+0.016 * 0.035$ (scandinor) $-0.006 * 0.465$ (otheror) $-0.020 * 0.061$ (mean) $+0.042 * 0.064$ (med) + $0.050 * 0.192$ (macc) $0.002 * 0.715$ (longt) $+0.009 * 0.878$ (impllong) -0.359 (intercept)
} 
Alternatively, we can define the best-practice estimate (Doucouliagos, 2016). This approach applies the significant characteristics of the study, which should correspond to the best practice in the field. Although such "best practice" estimate may be often controversial, it tries to correct the effect of wrongly specified studies rather than discarding these estimates and losing information on other research dimensions. For this approach, we use the preferred specification presented in the last part of Table 4. The best-practice estimate is given by the constant term and possibly the coefficient for DSGE, which gives a slightly more conservative value of -0.11 than the benchmark estimate.

\section{ROBUSTNESS ANALYSIS}

\subsection{Alternative estimation methods}

In order to control for different specification issues, Table 5 presents five robustness checks in addition to the preferred estimation in column (0). First, column (1) relies on the weighted least squares (WLS) method using the precision of each parameter estimate (defined by the inverse number reported estimates) as weights. We hereby account for relative quality differences within the standard specification, giving more weight to more precise and reliable estimates. Second, column (2) presents least absolute deviation (LAD) regression that minimizes the sum of absolute residuals to reduce the effect of large outliers on the estimated coefficients. Third, we present a robust regression based on Cook's (1977) distance measure (RR) that underweights the largest outliers (3). Fourth, the specification in column (4) controls for country-fixed effects (CFE). Finally, column (5) includes random effects for the underlying studies (SRE) to deal with potential cross-sectional dependence between estimates in the same study (Thompson and Sharp, 1999) and hence is expected to 
be a more reliable specification.

In general, the robustness checks do not change the results of the preferred estimation with regard to the included explanatory variables. Most importantly, the variables describing authors' affiliations are significant only in LAD regression and robust regression. Study random effects reduce also the significance level for the dummy variables describing methodological differences between the studies. Overall, the results are not found to be sensitive to estimation methods.

\subsection{META-PROBIT MODELS OF LARGE EFFECTS}

The standard meta-regressions presented in the previous sections suggest that the reported estimates of the primary studies tend to be mainly influenced by econometric modelling issues and the authors' affiliations. Moreover, publication bias is playing an important role in the literature on Basel III. Given the empirical evidence presented so far, it can be hypothesized that some studies try to support institutional views in presented publications on this topic. To investigate this issue more deeply, we estimate probit models whether the reported results can be considered as important from the policy point of view. Therefore, the reported effects are now regrouped into two categories, strong and negligible effects. To the best of our knowledge, this is the first meta-analysis proposing probabilistic models for nonnegligible effects.

In particular, using the reported effects of Basel III as measured so far by variable bsl, we define a new variable, strong, that takes value 1 if there is a strong effect, and 0 if negligible effects are reported,

$$
\text { strong }_{k i}=\left\{\begin{array}{ll}
1 & \text { if } b s l_{k i}<-0.25 \\
0 & \text { if } b s l_{k i} \geq-0.25
\end{array}\right. \text {. }
$$


The threshold for the identification of strong effects is identified as approximately the lowest quartile of the distribution of reported effects. Figure 2 shows also that the histogram of reported effects is characterized by a discontinuity of the distribution at this threshold level. Hence, the meta-regression for strong effects of Basel III can be estimated by probit models as follows,

$$
P\left(\text { strong }_{k i}=1\right)=\mu+\sum_{l=1}^{L} \beta_{l} D_{i k}+\omega_{k}+\varepsilon_{k i},
$$

where the explanatory variables are defined as in the standard meta-regression. 


\section{Table 6: Meta-probit regression of large effects}

\section{General model}

marg. prob.

Std. Err.

marg. prob.

Std. Err.

\begin{tabular}{|c|c|c|c|c|}
\hline Publication year & -0.034 & 0.030 & -0.006 & 0.019 \\
\hline Journal & -0.061 & 0.173 & & \\
\hline Working paper & -0.129 & 0.272 & & \\
\hline Public policy report & 0.062 & 0.273 & 0.308 & $0.166 * *$ \\
\hline Bank policy report & 0.901 & $\begin{array}{c}* * \\
0.019 *\end{array}$ & & \\
\hline Banking sector & -0.325 & $\begin{array}{c}* * \\
0.034 *\end{array}$ & & \\
\hline BIS & -0.200 & 0.165 & -0.181 & 0.092 \\
\hline Central Bank & -0.154 & 0.149 & -0.114 & $0.076 * *$ \\
\hline IMF & -0.077 & 0.207 & & \\
\hline European institutions & -0.218 & $0.071 * *$ & -0.151 & $0.072 * *$ \\
\hline OECD & -0.206 & $\begin{array}{c}* * \\
0.047 *\end{array}$ & -0.219 & $0.034 * *$ \\
\hline Bank-based system & -0.125 & 0.138 & & \\
\hline Market-based system & -0.254 & $0.091 * *$ & -0.146 & $0.058 * *$ \\
\hline French origin & -0.128 & 0.112 & & \\
\hline German origin & -0.111 & 0.121 & & \\
\hline Scandinavian origin & -0.134 & 0.104 & & \\
\hline Other origin & -0.043 & 0.163 & & \\
\hline Mean estimate & 0.025 & 0.125 & & \\
\hline Median estimate & -0.156 & $0.059 * *$ & & \\
\hline Accounting-based models & -0.042 & 0.122 & & \\
\hline VAR models & 0.311 & $0.153 *$ & 0.280 & $0.132 * *$ \\
\hline DSGE models & -0.148 & $0.063 *$ & -0.108 & 0.067 \\
\hline Macro-structural models & -0.204 & $0.088^{*}$ & -0.225 & $0.072 * *$ \\
\hline Long-term estimate & 0.064 & 0.066 & & \\
\hline Long-term impl. horizon & -0.009 & 0.077 & & \\
\hline Monetary policy offset & -0.204 & $\begin{array}{c}* * \\
0.043 * \\
\end{array}$ & -0.212 & $\begin{array}{c}* * \\
0.046 * \\
\end{array}$ \\
\hline No. of obs. & & 301 & & 301 \\
\hline Pseudo $\mathrm{R}^{2}$ & & 0.244 & & 0.206 \\
\hline Log-likelihood & & -128.568 & & -135.123 \\
\hline \multicolumn{5}{|c|}{$\begin{array}{l}\text { Note: *, **, and *** denote significance at the } 10 \%, 5 \% \text {, and } 1 \% \text { level, respectively. Marginal } \\
\text { probability effects evaluated at the means. Robust standard errors are in parentheses. Reference } \\
\text { categories (omitted variables): other publication format; authors affiliated with academic sector; } \\
\text { mixed financial system, English legal origin; regression-based approach. Variables FSA and CES were } \\
\text { dropped because they predict failure perfectly. } \\
\text { Source: Own estimations. }\end{array}$} \\
\hline
\end{tabular}


In general, the findings confirm the results of the previous analyses (see Table 6), moreover, some results are even stronger. Authors affiliated with central banks, European institutions, and the OECD show a significantly lower probability to publish large effects. As before, public sector studies tend to avoid a publication of strong effects. Similarly, there is a robust significant result that banking reports show higher probabilities to report strong effects. Market-based financial systems show a lower probability to report strong effects. The DSGE models are again insignificant, while macro-structural models are less likely to report strong effects. In turn, VAR models show a higher probability to publish large effects. Finally, studies that include a type of monetary policy offset are less likely to show strong effects.

\section{CONCLUSION}

The impact of financial reforms has become a core concern of the post-crisis era. Public policy debates focus on the question whether the new Basel rules will impose significant costs on the banking system and the broader economy. Despite a growing number of studies on this topic, especially in recent years, the empirical literature has reached highly ambiguous and inconclusive results. To tackle this issue, this paper synthesizes the empirical evidence from a unique dataset of 48 primary studies. We use meta-analysis techniques to identify the sources of heterogeneity.

Our meta-analysis of 48 primary studies provides four key findings. First, we find, on average, a relatively moderate effect on the real economy in response to a change in minimum capital requirements. The GDP level is expected to decrease by about -0.20 percent in response to one percentage point increase in the capital ratio, which broadly corresponds to benchmark results. In turn, best-practice results tend to be slightly lower (0.11 percent). The concern that financial regulation will greatly harm the economy is hence 
not reflected in most empirical studies. Second, studies in this field of research tend to be highly sensitive to specific modelling assumptions.

Finally, our contribution shows that there is comparably little research on the implications of Basel III reform on CEECs and emerging economies in general. The presented evidence shows that the impact on CEECs will be slightly higher than average impact mainly due to high importance of banking in these economies, although the impact on Slovakia could be relatively moderate in this region.

There is a high degree of uncertainty surrounding the estimates of primary studies. Our meta-analysis documents that this heterogeneity has also a significant impact on the main results. In general, estimates are mainly driven by modelling choices (with macro models tending to estimate lower impacts, compared to regression-based and VAR models) and the regional focus (with bank-based financial systems showing stronger effects compared to market-based systems). Finally, the surveyed studies may be distorted by publication bias. This can be attributed to a relatively strong theoretical consensus that tighter capital requirements will affect the real economy adversely. 


\section{Appendix}

Table A.1: List of surveyed studies

Akram, Q.F., 2014. Macro Effects of Capital Requirements and Macroprudential Policy. Economic Modelling 42, 77-93.

Angelini, P., Gerali, A., 2012. Banks' reactions to Basel-III. Working Paper No. 876, Banca d'Italia, Rome.

Angelini, A., Clerc, L., Cúrdia, V., Gambacorta, L., Gerali, A., Locarno, A., Motto, R., Roeger, W., Van den Heuvel, S., Vlček, J., 2015. Basel III: Long-term Impact on Economic Performance and Fluctuations. The Manchester School 83(2), 217-251.

Bank of Canada, 2010. Strengthening International Capital and Liquidity Standards: A Macroeconomic Impact Assessment for Canada, Bank of Canada Report, Ottawa.

Bank of England, 2010. Financial Stability Report No. 27, London.

Barrell, R., Davis, E.P., Fic, T., Holland, D., Kirby, S., Liadze, I., 2009. Optimal Regulation of Bank Capital and Liquidity: How To Calibrate New International Standards, Occasional Paper No. 38, Financial Services Authority, London.

BCBS, 2010. An Assessment of the Long-term Economic Impact of Stronger Capital and Liquidity Requirements. Basel Committee on Banking Supervision, Bank for International Settlements, Basel.

Berben, R-P., Bierut, B., van den End, J.W., Kakes, J., 2010. Macro-effects of Higher Capital and Liquidity Requirements for Banks: Empirical Evidence for the Netherlands, Occasional Studies 8(3), De Nederlandsche Bank NV, Amsterdam.

Bernabe, E., Jaffar, J., 2013. Gauging the Macroeconomic Impact of Basel III on Malaysia, SEACEN Staff Paper No. 87, South East Asian Central Banks Research and Training Centre, Kuala Lumpur.

Brooke, M., Bush, O., Edwards, R., Ellis, J., Francis, B., Harimohan, R., Neiss, K., Siegert, C., 2015. Measuring the Macroeconomic Costs and Benefits of Higher UK Bank Capital Requirements, Financial Stability Paper No. 35, Bank of England, London.

Cline, W.R., 2016. Benefits and Costs of Higher Capital Requirements for Banks, Working Paper No. 16, Peterson Institute for International Economics, Washington, D.C.

De Nicolò, G., 2015. Revisiting the Impact of Bank Capital Requirements on Lending and Real Activity, Mimeo, International Monetary Fund, Washington, D.C.

De Resende, C., Dib, A., Perevalov, N., 2010. The Macroeconomic Implications of Changes in Bank Capital and Liquidity Requirements in Canada: Insights from the BoC-GEMFIN, Discussion Paper No. 16, Bank of Canada, Ottawa.

Dorich, J., Zang, Y., 2010. Assessing the Macroeconomic Impact of Stronger Capital and Liquidity Requirements in Canada: Insights from ToTEM, Discussion Paper No. 9, Bank of Canada, Ottawa.

European Commission, 2011. Economic Impact of Changes in Capital Requirements in The EuroArea Banking Sector, Quarterly Report on the Euro Area 10(1), 26-31, Brussels.

FBF, 2010. Reforming of Prudential Rules Position of French Banks With Regard To Current Proposals, Working Paper, Fédération bancaire francaise, Paris.

Fic, T., 2014. Global Economic Policies and Developing Countries: NiGEM Scenarios for the Post2015 Agenda, Working Paper, National Institute of Economic and Social Research, London.

Gambacorta, L., 2011. Do Bank Capital and Liquidity Affect Real Economic Activity in the Long Run? AVECM Analysis for the US. Economic Notes 40(3), 75-91.

Giesecke, J.A., Dixon, P.B., Rimmer, M.T., 2016. The Costs and Benefits of Financial Regulation: A Financial CGE Assessment of the Impact of a Rise in Commercial Bank Capital Adequacy Ratios, Working Paper No. 104, Centre for International Finance and Regulation, Sydney.

IIF, 2011. The Cumulative Impact on the Global Economy of Proposed Changes in the Banking Regulatory Framework, Final Report, Institute of International Finance, Washington, D.C.

Junge, G., Kugler, P., 2012. Quantifying the Impact of Higher Capital Requirements on The Swiss Economy. Swiss Journal of Economics and Statistics 149(3), 313-356. 
Kashyap, A.K., Stein, J.S., Hanson, S., 2010. An Analysis of the Impact of 'Substantially Heightened' Capital Requirements on Large Financial Institutions, Mimeo, Booth School of Business, University of Chicago.

Kopp, E., Ragacs, C., Schmitz, S.W., 2010. The Economic Impact of Measures Aimed at Strengthening Bank Resilience - Estimates for Austria, Financial Stability Report No. 20, Oesterreichische Nationalbank, 86-114, Vienna.

Kragh-Sørensen, K., 2012. Optimal Capital Adequacy Ratios for Norwegian Banks, Staff Memo No. 29, Norges Bank, Oslo.

La Caixa, 2010. The Impact for Spain of the New Banking Regulations Proposed by the Basel Committee, Working Paper No. 1, Caja de Ahorros y Pensiones, Barcelona.

Locarno, A., 2011. The Macroeconomic Impact of Basel III on the Italian Economy, Istituto di Cultura Bancaria Francesco Parrillo, Rivista Bancaria - Minerva Bancaria, 5-6.

MAG, 2010a. Assessing the Macroeconomic Impact of the Transition to Stronger Capital and Liquidity Requirements, Interim Report, Macroeconomic Assessment Group, Bank for International Settlements, Basel, August.

MAG, 2010b. Assessing the Macroeconomic Impact of the Transition to Stronger Capital and Liquidity Requirements, Final Report, Macroeconomic Assessment Group, Bank for International Settlements, Basel, December.

Marchesi, M., Giudici, M.P., Cariboni, J., Zedda, S. Campolongo, F., 2012. Macroeconomic CostBenefit Analysis of Basel III Minimum Capital Requirements and of Introducing Deposit Guarantee Schemes and Resolution Funds, JRC Scientific and Policy Reports, European Commission, Luxembourg.

Miles, D., Yang, J., Marcheggiano, G., 2011. Optimal Bank Capital. The Economic Journal 123(567), 1-37.

Morgan, P.J., Pontines, V., 2013. An Asian Perspective on Global Financial Reforms, ADBI Working Paper 433, Asian Development Bank Institute, Tokyo.

Noss, J., Toffano, P., 2016. Estimating the Impact of Changes in Aggregate Bank Capital Requirements During an Upswing. Journal of Banking \& Finance 62(1), 15-27.

Oxford Economics, 2013. Analyzing the Impact of Bank Capital and Liquidity Regulations on US Economic Growth, The Clearing House Association, April.

Parcon-Santos, H.C., Bernabe, E.M., 2012. The Macroeconomic Effects of Basel III Implementation in the Philippines: A Preliminary Assessment, Working Paper No. 2, Bangko Sentral ng Pilipinas, Manila.

Reifner, U., Neuberger, D., Rissi, R., Clerc-Renaud, S., 2011. CRD IV - Impact Assessment of the Different Measures Within the Capital Requirements Directive IV, European Parliament, Brussels.

Roger, S., Vitek, F., 2012. The Global Macroeconomic Costs of Raising Bank Capital Adequacy Requirements, Working Paper No. 12/44, International Monetary Fund, Washington, D.C.

Roger, S., Vlcek, J., 2011. Macroeconomic Costs of Higher Bank Capital and Liquidity Requirements, Working Paper No. 11/103, International Monetary Fund, Washington, D.C.

Schanz, J., Aikman, D., Collazos, M.F., Gregory, D., Kapadia, S., 2011. The Long-Term Economic Impact of Higher Capital Levels, BIS Papers No. 60, 73-81, Bank for International Settlements, Basel.

Sinha, A., 2012. Financial Sector Regulation and Implications for Growth, BIS Papers No. 62, Bank for International Settlements, Basel.

Slovik, P., Cournède, B., 2011. Macroeconomic Impact of Basel III, Working Papers No. 844, OECD, Paris.

Son, J., 2013. The Effects and Policy Implications of Basel III in Korea. In: Basel III Implementation: Challenges and Opportunities, South East Asian Central Banks, Malaysia.

Sveriges Riksbank, 2011. Appropriate Capital Ratio in Major Swedish Banks - An Economic Analysis, Stockholm.

Sveriges Riksbank, 2014. Stricter Capital Requirements for Swedish Banks - Effects On The Macroeconomy, Monetary Policy Report, Stockholm. 
Sy, A., 2011. The Macrofinancial Impact of Basel III Capital Requirements. In: France: Selected Issues, International Monetary Fund, Washington, D.C.

Taskinsoy, J., 2013. Rigorous Capital Requirements Under Basel III: Possible Impact on Turkey's Financial Sector. Journal of WEI Business and Economics 2(1), 1-30.

Turrini, A., Roeger, W., Székely, I.P., 2010. Banking Crises, Output Loss and Fiscal Policy. CESifo Economic Studies 58(1), 181-219.

Wong, E., Fong, T., Li, K., Choi, H., 2010. An assessment of the Long-Term Economic Impact of the New Regulatory Reform on Hong Kong, Research Note No. 5, Hong Kong Monetary Authority, Hong Kong.

Yan, M., Hall, M.J.B., Turner, P., 2012. A Cost-Benefit Analysis of Basel III: Some Evidence From the UK. International Review of Financial Analysis 25, 73-82. 


\section{Table A2: Variable descriptions}

\begin{tabular}{|c|c|}
\hline Variables & Definitions \\
\hline \multicolumn{2}{|l|}{ Dependent variables } \\
\hline Basel & $\begin{array}{l}\text { GDP change in response to an increase in capital regulations } \\
\text { by } 1 \text { percentage point }\end{array}$ \\
\hline Strong & $\begin{array}{l}\text { Dummy variable: one if Basel is lower than }-0.25 \text { percent of } \\
\text { GDP, zero otherwise }\end{array}$ \\
\hline \multicolumn{2}{|l|}{ Publications } \\
\hline Publication year & $\begin{array}{l}\text { Continuous variable measured as the deviation from the mean } \\
\text { publication year. }\end{array}$ \\
\hline Journal & $\begin{array}{l}\text { Dummy variable: one if a study is published in a journal, zero } \\
\text { otherwise. }\end{array}$ \\
\hline Working paper & $\begin{array}{l}\text { Dummy variable: one if a study is published in a working } \\
\text { paper, zero otherwise. }\end{array}$ \\
\hline Public policy report & $\begin{array}{l}\text { Dummy variable: one if a study is published as a policy report } \\
\text { by public institutions, zero otherwise. }\end{array}$ \\
\hline Bank policy report & $\begin{array}{l}\text { Dummy variable: one if a study is published as a policy report } \\
\text { by banks or other private institutions, zero otherwise. }\end{array}$ \\
\hline \multicolumn{2}{|l|}{ Authors } \\
\hline Banking sector & $\begin{array}{l}\text { Dummy variable: one if an author is affiliated with the banking } \\
\text { sector, zero otherwise. }\end{array}$ \\
\hline Central Bank & $\begin{array}{l}\text { Dummy variable: one if an author belongs to Central Bank, } \\
\text { zero otherwise. }\end{array}$ \\
\hline BIS & $\begin{array}{l}\text { Dummy variable: one if an author belongs to BIS (Bank of } \\
\text { International Settlement), zero otherwise. }\end{array}$ \\
\hline IMF & $\begin{array}{l}\text { Dummy variable: one if an author belongs to IMF } \\
\text { (International Monetary Fund), zero otherwise. }\end{array}$ \\
\hline European Institution & $\begin{array}{l}\text { Dummy variable: one if an author belongs to European } \\
\text { Institution (European Commission / European Parliament), zero } \\
\text { otherwise. }\end{array}$ \\
\hline OECD & $\begin{array}{l}\text { Dummy variable: one if an author belongs to OECD } \\
\text { (Organisation for Economic Co-operation and Development), } \\
\text { zero otherwise. }\end{array}$ \\
\hline FSA & $\begin{array}{l}\text { Dummy variable: one if an author belongs to FSA (Financial } \\
\text { Services Authority), zero otherwise. }\end{array}$ \\
\hline \multicolumn{2}{|l|}{ Financial systems } \\
\hline Market-based system & $\begin{array}{l}\text { Dummy variable: one for countries with a market-based } \\
\text { financial system (Australia, Canada, Hong Kong, India, } \\
\text { Malaysia, South Africa, UK, and US), zero otherwise. }\end{array}$ \\
\hline Bank-based system & $\begin{array}{l}\text { Dummy variable: one for the remaining countries, zero } \\
\text { otherwise. }\end{array}$ \\
\hline Mixed system & $\begin{array}{l}\text { Dummy variable: one if a study includes a broader region with } \\
\text { different financial systems, zero otherwise. }\end{array}$ \\
\hline
\end{tabular}




\begin{tabular}{|c|c|}
\hline \multicolumn{2}{|l|}{ Legal origins } \\
\hline English origin & $\begin{array}{l}\text { Dummy variable: one for country with an English origin } \\
\text { (Australia, Canada, Cyprus, Hong Kong, India, Ireland, } \\
\text { Malaysia, South Africa, UK, and US), zero otherwise. }\end{array}$ \\
\hline French origin & $\begin{array}{l}\text { Dummy variable: one for country with a French origin } \\
\text { (Belgium, Brazil, France, Greece, Italy, Luxemburg, Malta, } \\
\text { Mexico, Netherlands, Philippines, Portugal, Spain, and Turkey), } \\
\text { zero otherwise. }\end{array}$ \\
\hline German origin & $\begin{array}{l}\text { Dummy variable: one for country with a German origin } \\
\text { (Austria, Germany, Japan, Korea, and Switzerland), zero } \\
\text { otherwise. }\end{array}$ \\
\hline Scandinavian origin & $\begin{array}{l}\text { Dummy variable: one for a country with a Scandinavian origin } \\
\text { (Denmark, Finland, Norway, and Sweden), zero otherwise. }\end{array}$ \\
\hline \multicolumn{2}{|l|}{ Model classes } \\
\hline $\begin{array}{l}\text { Regression-based } \\
\text { models }\end{array}$ & $\begin{array}{l}\text { Dummy variable: one if a study is based on a regression-based } \\
\text { approach (OLS, ML, GMM, ECM), zero otherwise. }\end{array}$ \\
\hline Mean estimate & $\begin{array}{l}\text { Dummy variable: one if a study is based on a mean estimate, } \\
\text { zero otherwise. }\end{array}$ \\
\hline Median estimate & $\begin{array}{l}\text { Dummy variable: one if a study is based on a median estimate, } \\
\text { zero otherwise. }\end{array}$ \\
\hline $\begin{array}{l}\text { Accounting-based } \\
\text { models }\end{array}$ & $\begin{array}{l}\text { Dummy variable: one if a study is based on an accounting- } \\
\text { based approach (balance sheet identities), zero otherwise. }\end{array}$ \\
\hline DSGE models & $\begin{array}{l}\text { Dummy variable: one if a study is based on a DSGE (dynamic } \\
\text { stochastic equilibrium) model, zero otherwise. }\end{array}$ \\
\hline VAR models & $\begin{array}{l}\text { Dummy variable: one if a study is based on a VAR (vector } \\
\text { auto-regression) model, zero otherwise. }\end{array}$ \\
\hline Macro-structural models & $\begin{array}{l}\text { Dummy variable: one if a study is based on a structural } \\
\text { macroeconomic model, zero otherwise. }\end{array}$ \\
\hline CES models & $\begin{array}{l}\text { Dummy variable: one if a study is based on a CES (constant } \\
\text { elasticity of substitution) production function, zero otherwise. }\end{array}$ \\
\hline \multicolumn{2}{|l|}{$\begin{array}{l}\text { Modelling } \\
\text { assumptions }\end{array}$} \\
\hline Long-term estimate & $\begin{array}{l}\text { Dummy variable: one if a study is based on a long-term } \\
\text { estimate, zero otherwise. }\end{array}$ \\
\hline $\begin{array}{l}\text { Long-term } \\
\text { implementation horizon }\end{array}$ & $\begin{array}{l}\text { Dummy variable: one if a study is based on a long-term } \\
\text { implementation horizon, zero otherwise. }\end{array}$ \\
\hline Monetary policy & $\begin{array}{l}\text { Dummy variable: one if a study includes active monetary } \\
\text { policy, zero otherwise. }\end{array}$ \\
\hline
\end{tabular}




\section{Table A.3: Descriptive statistics}

\begin{tabular}{|c|c|c|c|c|c|}
\hline Variable & Observations & Mean & St dev. & Min & Max \\
\hline Basel impact & 312 & -0.198 & 0.155 & -0.850 & -0.01 \\
\hline Strong Basel impact & 312 & 0.244 & 0.430 & 0 & 1 \\
\hline Publication year & 312 & 2010 & 1.482 & 2008 & 2015 \\
\hline Journal & 312 & 0.067 & 0.251 & 0 & 1 \\
\hline Working paper & 312 & 0.554 & 0.498 & 0 & 1 \\
\hline Public policy report & 312 & 0.212 & 0.409 & 0 & 1 \\
\hline Bank policy report & 312 & 0.083 & 0.277 & 0 & 1 \\
\hline Other publication & 312 & 0.083 & 0.277 & 0 & 1 \\
\hline Banking sector & 312 & 0.090 & 0.286 & 0 & 1 \\
\hline BIS & 312 & 0.279 & 0.449 & 0 & 1 \\
\hline Central Bank & 312 & 0.208 & 0.407 & 0 & 1 \\
\hline IMF & 312 & 0.183 & 0.387 & 0 & 1 \\
\hline Europ. Institution & 312 & 0.115 & 0.320 & 0 & 1 \\
\hline OECD & 312 & 0.048 & 0.214 & 0 & 1 \\
\hline FSA & 312 & 0.006 & 0.080 & 0 & 1 \\
\hline Academic institution & 312 & 0.071 & 0.256 & 0 & 1 \\
\hline Market-based system & 312 & 0.237 & 0.426 & 0 & 1 \\
\hline Bank-based system & 312 & 0.667 & 0.472 & 0 & 1 \\
\hline Mixed system & 312 & 0.099 & 0.300 & 0 & 1 \\
\hline French origin & 312 & 0.138 & 0.345 & 0 & 1 \\
\hline German origin & 312 & 0.106 & 0.308 & 0 & 1 \\
\hline Scandinavian origin & 312 & 0.035 & 0.185 & 0 & 1 \\
\hline Other origin & 312 & 0.465 & 0.500 & 0 & 1 \\
\hline English origin & 312 & 0.256 & 0.437 & 0 & 1 \\
\hline Mean estimate & 312 & 0.061 & 0.240 & 0 & 1 \\
\hline Median estimate & 312 & 0.064 & 0.245 & 0 & 1 \\
\hline Accounting-based models & 312 & 0.192 & 0.395 & 0 & 1 \\
\hline VAR models & 312 & 0.061 & 0.240 & 0 & 1 \\
\hline DSGE models & 312 & 0.112 & 0.316 & 0 & 1 \\
\hline Macro-structural models & 312 & 0.231 & 0.422 & 0 & 1 \\
\hline Production function models & 312 & 0.032 & 0.176 & 0 & 1 \\
\hline Regression models & 312 & 0.247 & 0.432 & 0 & 1 \\
\hline Long-term estimate & 312 & 0.715 & 0.452 & 0 & 1 \\
\hline Long-term implem. horizon & 312 & 0.878 & 0.328 & 0 & 1 \\
\hline Monetary policy offset & 312 & 0.170 & 0.376 & 0 & 1 \\
\hline
\end{tabular}


Table B.1: Detailed summary of methodologies used in the individual reviewed studies

\begin{tabular}{|c|c|c|}
\hline Approach & $\begin{array}{l}\text { Description of the modelling } \\
\text { approach }\end{array}$ & Studies using this approach \\
\hline $\begin{array}{l}\text { 1. Accounting-based } \\
\text { approaches: } \\
\text { 'The loan pricing } \\
\text { model' proposed by } \\
\text { Elliott (2009) }\end{array}$ & $\begin{array}{l}\text { The accounting-based approach is built } \\
\text { upon a simple loan pricing equation, as } \\
\text { proposed by Elliott (2009). The studies } \\
\text { using this equation first evaluate the } \\
\text { impact of increasing capital ratios on } \\
\text { bank's cost of funding (WACC) using } \\
\text { aggregate bank balance sheet data. In a } \\
\text { second step, they calculate the lending }\end{array}$ & $\begin{array}{l}\text { Kashyap et al. (2010) use an approach that is based on the calibration } \\
\text { of lending spreads (through an increase in the WACC). } \\
\text { Kopp et al. (2010) use financial accounts data for Austria (2009). The } \\
\text { spread effects derived from the loan pricing equation are used as input } \\
\text { factors for the OeNB's macroeconomic Austrian quarterly model (AQM). } \\
\text { La Caixa (2010) uses a two-step approach (accounting-based model and } \\
\text { semi-structural macro-econometric model). }\end{array}$ \\
\hline
\end{tabular}
spread that would be needed to keep the lending spread effects are then used as input parameters for different macroeconomic models that do not incorporate a banking sector. While this approach is intuitive, it has several drawbacks. It is, for instance, not possible to disentangle demand and supply effects.

IIF (2011) uses a two-step approach, whereby input factors are calculated from a accounting-based model (lending spread effects derived from a loan pricing equation).

Reifner et al. (2011) use Bankscope data for several EU countries (averages for the period 2000-2010). The lending spread effects derived from changes in banks' WACC are then used as input parameters for the ECB's semi-structural macroeconomic model.

Slovik \& Cournede (2011) use aggregate bank balance sheet data for the US, the Euro Area and Japan (data averaged over 2004-2006). The semi-elasticities are then used as input factors for the OECD New Global Model.

Sy (2011) uses Bank de France data on the French aggregate banking sector (2003-2007). The spread adjustments serve as input factors into a Bank de France semi-structural model.

Oxford Economics (2013) uses the semi-elasticities calculated by Slovik \& Cournède (2011) as input factors for the Oxford Global Economic Model (large scale macroeconomic forecasting model).

Taskinsoy (2013) uses a two-step approach based on accounting identities. Spread effects serve as input parameters into a semi-structural macro-econometric model.

Brooke et al. (2015) first derive the increase in lending spreads, using a basic loan pricing equation. The spread effects are then used as input factors into different semi-structural macroeconomic models. 


\begin{tabular}{|c|c|c|}
\hline $\begin{array}{l}\text { 2. Regression-based } \\
\text { approaches: Vector } \\
\text { Error Correction } \\
\text { Model (VECM), Error } \\
\text { Correction Model } \\
\text { (ECM) }\end{array}$ & $\begin{array}{l}\text { The credit spread model } \\
\text { This approach is built upon the Error } \\
\text { Correction Model (ECM), using aggregate } \\
\text { historical bank data. The credit spread } \\
\text { model was proposed by Barrell (2009). } \\
\text { The VECM model is used to estimate a } \\
\text { long-term relationship between a small } \\
\text { set of macro variables. Most studies } \\
\text { assess the relationships between the } \\
\text { capital adequacy ratio, lending spreads } \\
\text { and economic output. The models are } \\
\text { fully estimated and explicitly feature a } \\
\text { banking sector (bank adjustment through } \\
\text { lending spreads). } \\
\text { The target capital ratio model } \\
\text { An alternative approach was proposed by } \\
\text { Francis \& Osborne (2009) and relies on } \\
\text { earlier work by Hancock \& Wilcox (1994, } \\
\text { 1998). The target capital ratio model first } \\
\text { calculates the gap between the actual } \\
\text { and the target capital ratio and derives a } \\
\text { 'distance-from-target variable that is then } \\
\text { used to regress the responses of } \\
\text { different balance sheet items. }\end{array}$ & 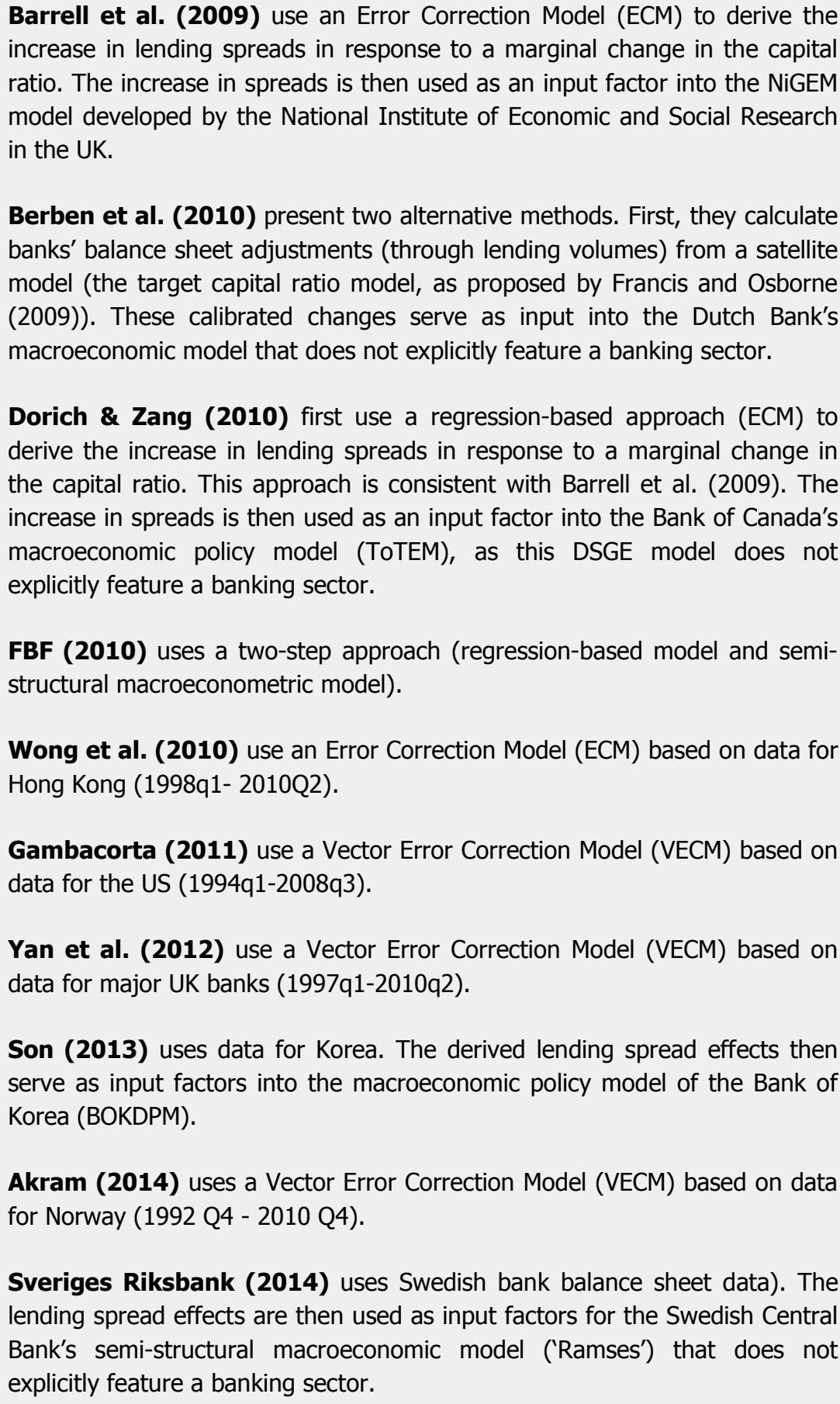 \\
\hline
\end{tabular}

Barrell et al. (2009) use an Error Correction Model (ECM) to derive the in lending spreads in response to a marginal change in the capital model developed by the National Institute of Economic and Social Research Berben et al. (2010) present two alternative methods. First, they calculate banks' balance sheet adjustments (through lending volumes) from a satellite model (the target capital ratio model, as proposed by Francis and Osborne (2009)). These calibrated changes serve as input into the Dutch Bank's Dorich \& Zang (2010) first use a regression-based approach (ECM) to derive the increase in lending spreads in response to a marginal change in roeconomic policy model (TOTEM), as this DSGE model does not Francis \& Osborne (2009) and relies on earlier work by Hancock \& Wilcox (1994, 'distance-from-target variable that is then explicitly feature a banking sector. 


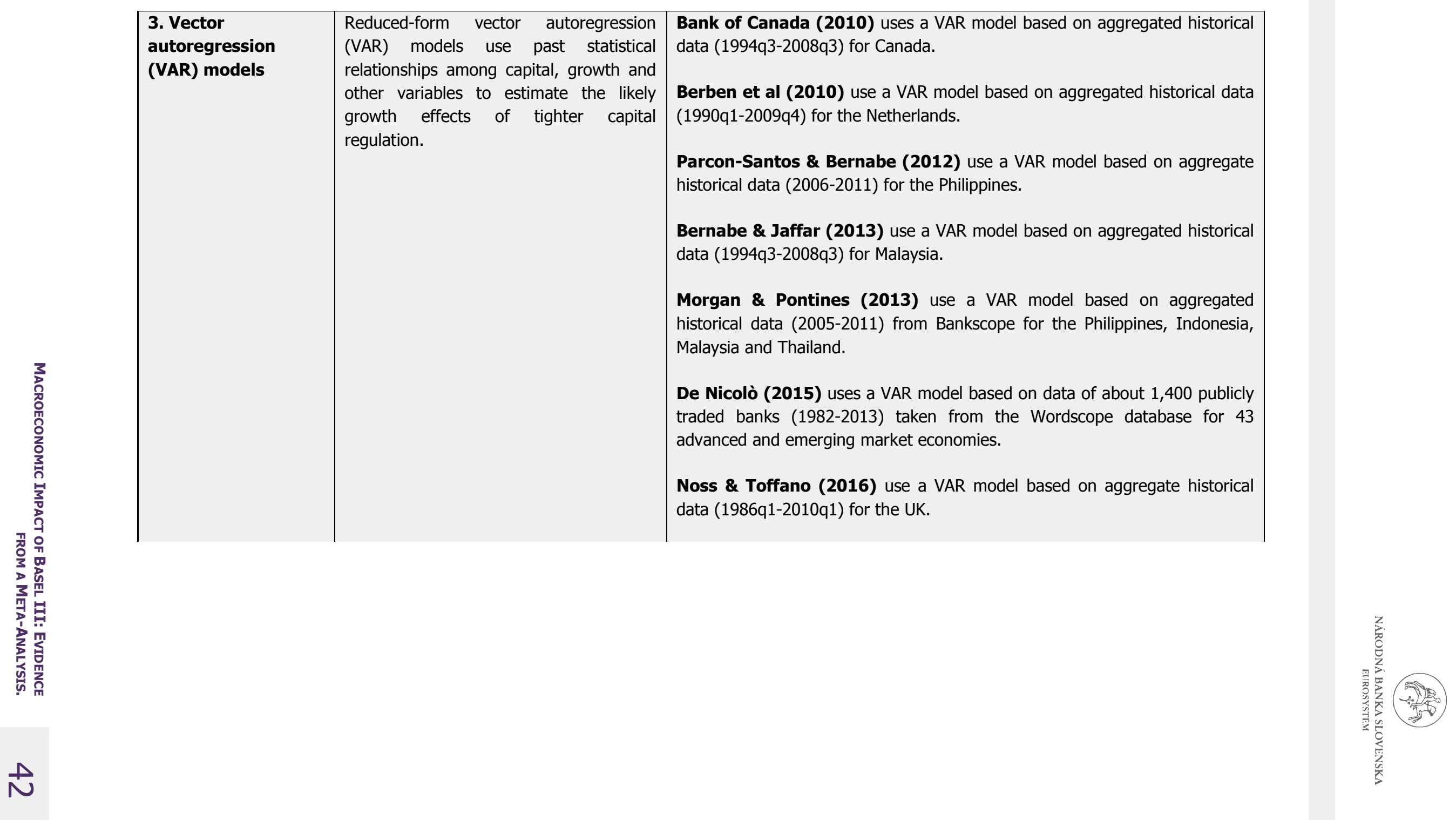




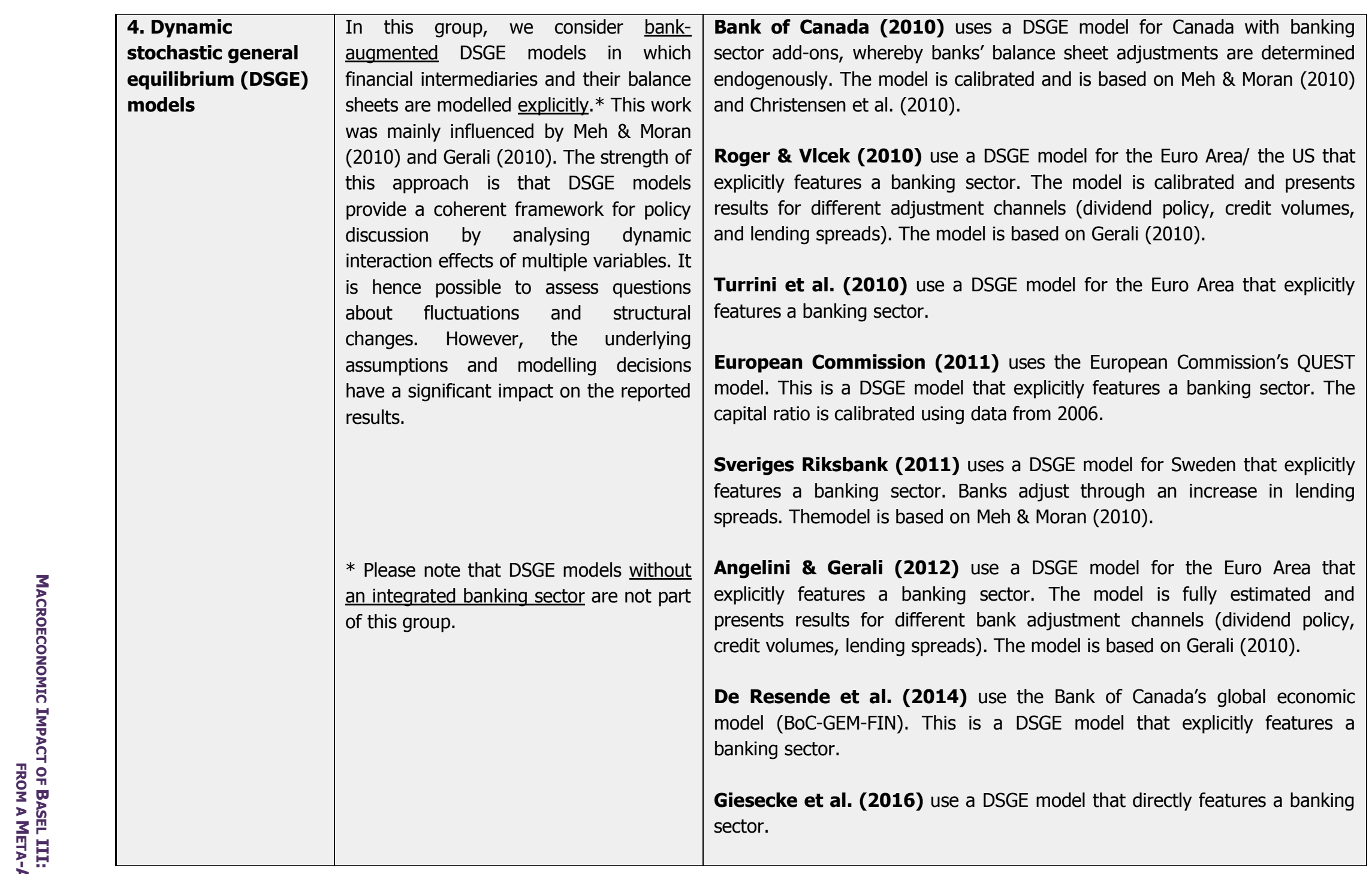




\begin{tabular}{|c|c|c|}
\hline $\begin{array}{l}\text { 5. Macro-structural } \\
\text { models }\end{array}$ & $\begin{array}{l}\text { In this category, we include further } \\
\text { macro-structural modeling approaches. }\end{array}$ & $\begin{array}{l}\text { Fic (2014) uses the global econometric model by the National Institute of } \\
\text { Economic and Social Research (NiGEM). } \\
\text { Kragh-Sørensen (2012) uses a semi-structural model, the Norges Bank's } \\
\text { Financial Stability Model (FSM), which directly includes a relationship for } \\
\text { capital adequacy. } \\
\text { Locarno (2011) uses the Bank of Italy Quarterly Model (BIQM), a semi- } \\
\text { structural large-scale econometric model. } \\
\text { Roger \& Vitek (2012) use a structural macroeconometric model that } \\
\text { explicitly features a banking sector. The model is fully estimated. } \\
\text { Sinha (2012) presents macroeconomic model developed at the Reserve } \\
\text { Bank of India (RBI) that explicitly features a banking sector (estimating } \\
\text { structural equations for 1996-2010). }\end{array}$ \\
\hline $\begin{array}{l}\text { 6. Production } \\
\text { function models }\end{array}$ & $\begin{array}{l}\text { The long-run impact of higher bank } \\
\text { lending spreads on GDP is assessed using } \\
\text { a simple (Cobb-Douglas or CES) } \\
\text { production function. In this framework, } \\
\text { an increase in non-financial firms' cost of } \\
\text { capital (WACC) reduces their investment } \\
\text { and, ultimately, the level of GDP. This } \\
\text { approach was proposed by Bank of } \\
\text { England (2010). This approach is very } \\
\text { intuitive, but it is not possible to perform } \\
\text { a deeper analysis within this framework. }\end{array}$ & $\begin{array}{l}\text { Bank of England (2010) uses a Cobb-Douglas production function. } \\
\text { Cline (2010) use a CES production function. } \\
\text { Miles et al. (2011) use a CES production function. } \\
\text { Schanz et al. (2011) use a CES production function. } \\
\text { Junge \& Kugler (2012) use a CES production function. } \\
\text { Marchesi et al. (2012) use a Cobb-Douglas production function. }\end{array}$ \\
\hline $\begin{array}{l}\text { 7. Meta-estimates: } \\
\text { Mean and median } \\
\text { from meta-studies }\end{array}$ & $\begin{array}{l}\text { Meta-estimates are derived from a } \\
\text { variety of different model classes (e.g. } \\
\text { DSGE models, VAR models and semi- } \\
\text { structural models) and are then } \\
\text { presented as mean or median estimates } \\
\text { in the corresponding meta-studies. }\end{array}$ & $\begin{array}{l}\text { BCBS (2010) presents meta-estimates for different model classes (including } \\
\text { DSGE models and semi-structural models). } \\
\text { MAG (2010a) presents meta-estimates based on a variety of methods } \\
\text { (including DSGE models, VAR models and semi-structural models). } \\
\text { MAG (2010b) presents meta-estimates based on a variety of methods } \\
\text { (including DSGE models, VAR models and semi-structural models). } \\
\text { Angelini et al. (2015) present meta-estimates for different model classes } \\
\text { (including DSGE models and semi-structural models). }\end{array}$ \\
\hline
\end{tabular}




\section{REFERENCES}

Admati, A.R., DeMarzo, P.M., Hellwig, M.F., Pfleiderer, P., 2013. Fallacies, Irrelevant Facts, and Myths in the Discussion of Capital Regulation: Why Bank Equity is Not Socially Expensive, Working Paper Series of the Max Planck Institute for Research on Collective Goods No. 23, Max Planck Institute for Research on Collective Goods, Bonn.

Admati, A.R., Hellwig, M., 2013. The Bankers' New Clothes: What's Wrong with Banking and What to Do about It, Princeton University Press, Princeton.

Ashenfelter, O., Harmon, C., Oosterbeek, H., 1999. A Review of Estimates of the Schooling/ Earnings Relationship, With Tests for Publication Bias. Labour Economics 6(4), 453-470.

BCBS, 2010a. An Assessment of the Long-term Economic Impact of Stronger Capital and Liquidity Requirements, Basel Committee on Banking Supervision, Bank for International Settlements, Basel.

BCBS, 2010b. Strengthening the Resilience of the Banking Sector, Consultative Document, Basel Committee on Banking Supervision, Bank for International Settlements, Basel.

BCBS, 2010c. Results of the Comprehensive Quantitative Impact Study, Basel Committee on Banking Supervision, Bank for International Settlements, Basel.

BCBS, 2011. The Transmission Channels Between the Financial and Real Sectors: A Critical Survey of the Literature, Working Paper, Basel Committee on Banking Supervision, Bank for International Settlements, Basel.

Beck, T., Levine, R., 2002. Industry Growth and Capital Allocation: Does Having a Market- or Bank-Based System Matter? Journal of Financial Economics 64(2), 147-180.

Beck, T., Levine, R., 2004. Stock Markets, Banks, and Growth: Panel Evidence. Journal of Banking \& Finance 28(3), 423-442.

Bernanke, B.S., Gertler, M., 1995. Inside the Black Box: The Credit Channel of Monetary Policy Transmission. Journal of Economic Perspectives 9(4), 27-48.

Card, D., Krueger, A.B., 1995. Time-Series Minimum-Wage Studies: A Meta-Analysis. American Economic Review 85(2), 238-243.

Card, D., Kluve, J., Weber, A., 2010. Active Labour Market Policy Evaluations: A MetaAnalysis. Economic Journal 120(548), 452-477.

Cook, R.D., 1977. Detection of Influential Observation in Linear Regression. Technometrics 19(1), 15-18.

Cosimano, T.F., Hakura, D., 2011. Bank Behavior in Response to Basel III: A Cross-Country Analysis, IMF Working Papers 11/119, International Monetary Fund, Washington, D.C. 
Doucouliagos, H. 2016. Meta-regression analysis: Producing credible estimates from diverse evidence. IZA World of Labor, Institute for the Study of Labor (IZA), pp. 320-320.

Dewatripont, M., Tirole, J., 1994. The Prudential Regulation of Banks, MIT Press, Cambridge, MA.

Elliott, D. J., 2009. Quantifying the Effects on Lending of Increased Capital Requirements, Working Paper, The Brookings Institution, Washington, D.C.

Egger, M., Smith, G.D., Scheider, M., Minder, C., 1997. Bias in Meta-Analysis Detected by a Simple, Graphical Test. British Medical Journal 316, 629-634.

Feld, L. P., Heckemeyer, J. H., Overesch, M., 2013. Capital structure choice and company taxation: A meta-study. Journal of Banking and Finance 37(8), 2850-2866.

Fidrmuc, J., Korhonen, I., 2006. Meta-Analysis of the Business Cycle Correlation Between the Euro Area and the CEECs. Journal of Comparative Economics 34(3), 518-537.

Fidrmuc, J., Korhonen, I., 2015. Meta-Analysis of Chinese Business Cycle Correlation, Working Paper No. 6, Hong Kong Institute for Monetary Research, Hong Kong.

Francis, W., Osborne, M., 2009. Bank Regulation, Capital and Credit Supply: Measuring the Impact of Prudential Standards, Occasional Papers No. 36, Financial Services Authority, London.

Friedman, B., 1991. Comment on "The Credit Crunch", by Ben S. Bernanke and Cara S. Lown. Brookings Papers on Economic Activity No. 2, 240-247.

Gambacorta, L., Mistrulli, P.E., 2004. Does Bank Capital Affect Lending Behavior? Journal of Financial Intermediation 13(4), 436-457.

Hancock, D., Wilcox, J., 1993. Has There Been a 'Capital Crunch' in Banking? The Effects on Bank Lending of Real Estate Market Conditions and Bank Capital Shortfalls. Journal of Housing Economics 3(1), 31-50.

Hancock, D., Wilcox, J., 1994. Bank Capital and Credit Crunch: The Roles of Risk-Weighted and Unweighted Capital Regulations. Journal of the American Real Estate and Urban Economics Association 22(1), 59-94

Havránek, T., Iršová, Z., 2011. Estimating Vertical Spillovers from FDI: Why Results Vary and what the True Effect Is. Journal of International Economics 85(2), 234-244.

Havránek, T., Rusnák, M. 2013. Transmission Lags of Monetary Policy: A Meta-Analysis," International Journal of Central Banking 9(4), 39-76.

Havránek, T., Horváth, R., Iršová, Z., Rusnák, M., 2015. Cross-Country Heterogeneity in Intertemporal Substitution. Journal of International Economics 96(1), 100-118.

Holmstrom, B., Tirole,J., 1997. Financial Intermediation, Loanable Funds, and the Real Sector. The Quarterly Journal of Economics 112(3), 663-691. 
Kim, D, Santomero, A. M., 1988. Risk in Banking and Capital Regulation. The Journal of Finance 43(5), 1219-1233.

La Porta, R., Lopez-de-Silanes, F., Shleifer, A., Vishny, R.W., 1998. Law and Finance. Journal of Political Economy 106(6), 1113-1155.

Levine, R., 2002. Bank-Based or Market-Based Financial Systems: Which Is Better? Journal of Financial Intermediation 11(4), 398-428.

Levine, R., Zervos, S., 1998. Stock Markets, Banks, and Economic Growth. The American Economic Review 88, 537-558.

Meh, C.A., Moran, K., 2010. The Role of Bank Capital in the Propagation of Shocks. Journal of Economic Dynamics \& Control 34, 555-576.

Roeger, W., Veld, J., 2004. Some Selected Simulation Experiments with the European Commission's QUEST Model. Economic Modelling 21(5), 785-832.

Stanley, T. D., 2001. Wheat from Chaff: Meta-Analysis as Quantitative Literature Review. Journal of Economic Perspectives 15(3), 131-150.

Stanley, T.D., 2005. Beyond Publication Bias. Journal of Economic Surveys 19, 309-345.

Stanley, T. D., 2008. Meta-Regression Methods for Detecting and Estimating Empirical Effects in the Presence of Publication Selection. Oxford Bulletin of Economics and Statistics 70(1), 103-127.

Stanley, T.D., Jarrell, S.B., 2005. Meta-Regression Analysis: A Quantitative Method of Literature Surveys. Journal of Economic Surveys 19(3), 299-308.

Stanley, T. D. Doucouliagos, H., 2012. Meta Regression Analysis in Economics and Business, Routledge, New York.

Sutton, A. J., Duval, S. J., Tweedie, R. L., Abrams, K. R., Jones, D. R., 2000a. Empirical Assessment of Effect of Publication Bias on Meta-Analyses. British Medical Journal 320, 1574-77.

Sutton, A. J., Abrams, K. R., Jones, D. R., Sheldon, T. A., Song, F., 2000b. Methods for Meta-Analysis in Medical Research. John Wiley \& Sons, Chichester.

Thompson, S.G., Sharp, S.J., 1999. Explaining Heterogeneity in Meta-Analysis: a Comparison of Methods. Statistics in Medicine 18, 2693-2708.

Van den Heuvel, S.K., 2008. The Welfare Cost of Bank Capital Requirements. Journal of Monetary Economics 55(2), 298-320.

VanHoose, D., 2007. Theories of Bank Behavior under Capital Regulation. Journal of Banking \& Finance 31(12), 3680-3697. 